\title{
Water Sorption and Radiolysis Studies for Neptunium Oxides
}

\section{January 2004}

Prepared by

A. S. Icenhour

R. M. Wham

R. R. Brunson

L. M. Toth 


\section{DOCUMENT AVAILABILITY}

Reports produced after January 1, 1996, are generally available free via the U.S. Department of Energy (DOE) Information Bridge:

Web site: http://www.osti.gov/bridge

Reports produced before January 1, 1996, may be purchased by members of the public from the following source:

National Technical Information Service

5285 Port Royal Road

Springfield, VA 22161

Telephone: 703-605-6000 (1-800-553-6847)

TDD: $703-487-4639$

Fax: 703-605-6900

E-mail: info@ntis.fedworld.gov

Web site: http://www.ntis.gov/support/ordernowabout.htm

Reports are available to DOE employees, DOE contractors, Energy Technology Data Exchange (ETDE) representatives, and International Nuclear Information System (INIS) representatives from the following source:

Office of Scientific and Technical Information

P.O. Box 62

Oak Ridge, TN 37831

Telephone: 865-576-8401

Fax: 865-576-5728

E-mail: reports@adonis.osti.gov

Web site: http://www.osti.gov/contact.html

This report was prepared as an account of work sponsored by an agency of the United States Government. Neither the United States government nor any agency thereof, nor any of their employees, makes any warranty, express or implied, or assumes any legal liability or responsibility for the accuracy, completeness, or usefulness of any information, apparatus, product, or process disclosed, or represents that its use would not infringe privately owned rights. Reference herein to any specific commercial product, process, or service by trade name, trademark, manufacturer, or otherwise, does not necessarily constitute or imply its endorsement, recommendation, or favoring by the United States Government or any agency thereof. The views and opinions of authors expressed herein do not necessarily state or reflect those of the United States Government or any agency thereof. 
ORNL/TM-2003/194

\title{
WATER SORPTION AND RADIOLYSIS STUDIES FOR NEPTUNIUM OXIDES
}
A. S. Icenhour
R. M. Wham
R. R. Brunson
L. M. Toth

Date Published: January 2004

\author{
Prepared by \\ OAK RIDGE NATIONAL LABORATORY \\ P.O. Box 2008 \\ Oak Ridge, Tennessee 37831-6285 \\ managed by \\ UT-Battelle, LLC \\ for the \\ U.S. DEPARTMENT OF ENERGY \\ under contract DE-AC05-00OR22725
}





\section{CONTENTS}

Page

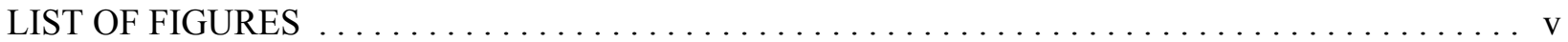

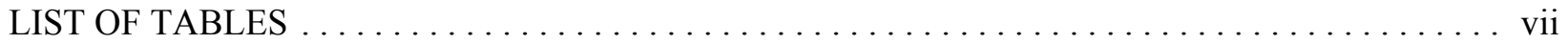

ACRONYMS, ABBREVIATIONS, AND DEFINITIONS $\ldots \ldots \ldots \ldots \ldots \ldots \ldots \ldots \ldots \ldots$ ix

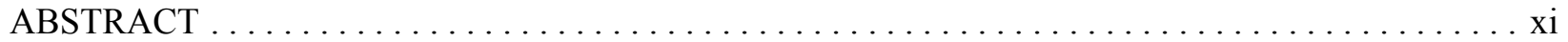

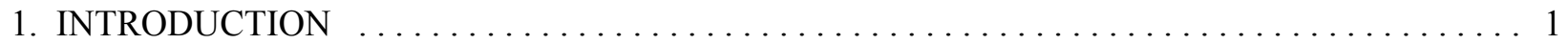

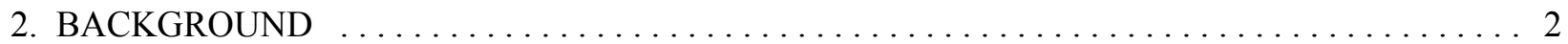

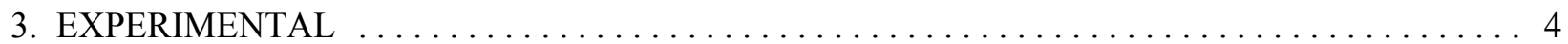

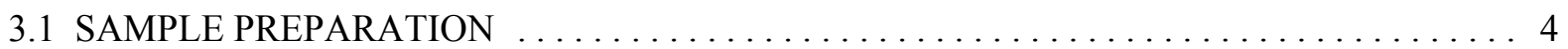

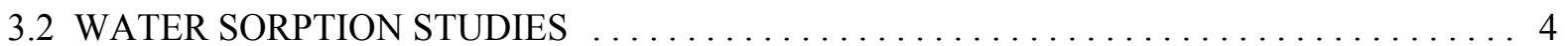

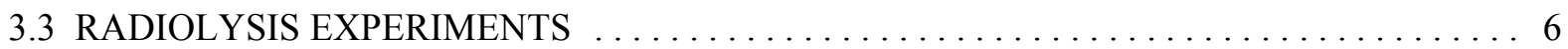

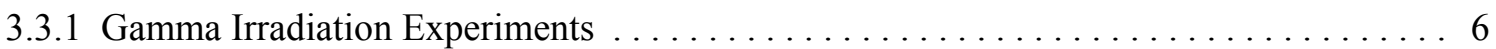

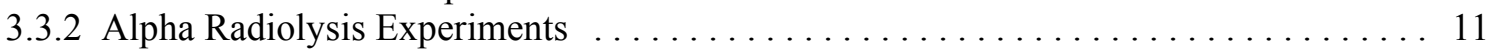

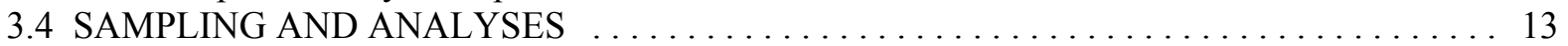

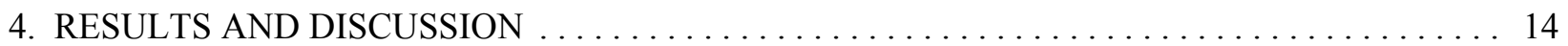

4.1 WATER SORPTION EXPERIMENTS $\ldots \ldots \ldots \ldots \ldots \ldots \ldots \ldots \ldots \ldots \ldots \ldots \ldots \ldots \ldots \ldots \ldots$

4.2 GAMMA RADIOLYSIS EXPERIMENTS $\ldots \ldots \ldots \ldots \ldots \ldots \ldots \ldots \ldots \ldots \ldots \ldots \ldots \ldots \ldots$

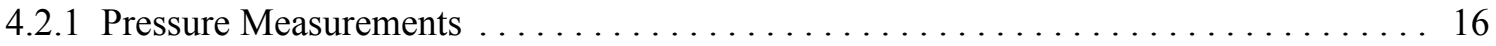

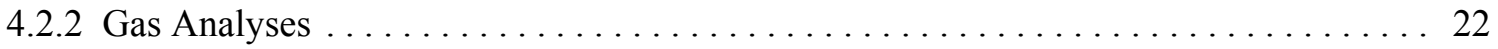

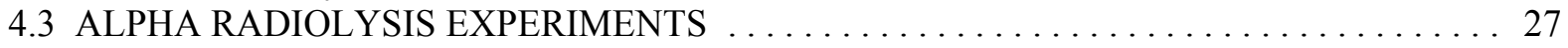

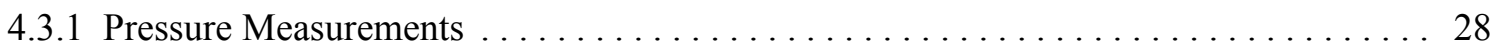

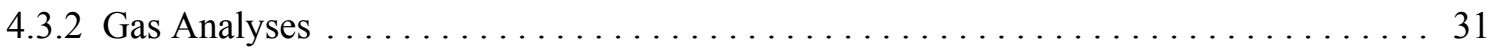

4.4 OVERVIEW OF RADIOLYTIC MECHANISM $\ldots \ldots \ldots \ldots \ldots \ldots \ldots \ldots \ldots \ldots \ldots \ldots$

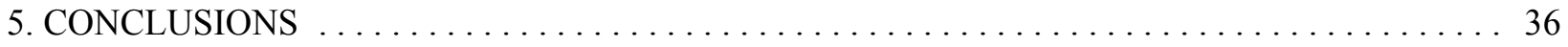

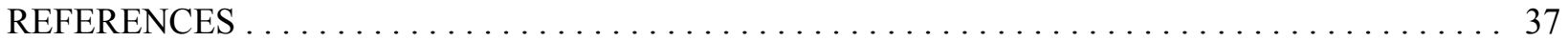





\section{LIST OF FIGURES}

Figure

Page

2.1 Schematic depiction of neptunium processing and packaging. $\ldots \ldots \ldots \ldots \ldots \ldots \ldots$

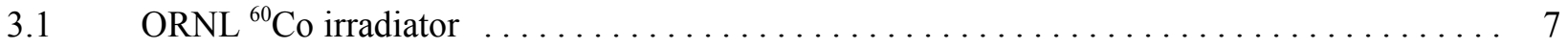

3.2 Sample container and pressure transducer used in the ${ }^{60} \mathrm{Co}$ irradiations. $\ldots \ldots \ldots \ldots \ldots$

3.3 Irradiation chamber of ORNL ${ }^{60} \mathrm{Co}$ irradiator with sample containers installed. $\ldots \ldots \ldots \quad 8$

3.4 Data acquisition computer in operation at the ORNL ${ }^{60} \mathrm{Co}$ source $\ldots \ldots \ldots \ldots \ldots \ldots$

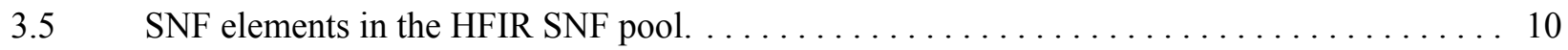

3.6 Schematic of the experimental configuration for gamma irradiation experiments

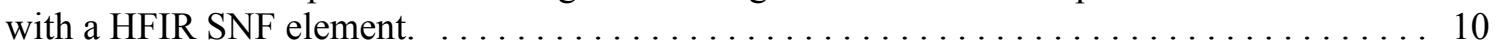

3.7 Multiple-irradiation container used in HFIR SNF irradiations. $\ldots \ldots \ldots \ldots \ldots \ldots \ldots \ldots 11$

3.8 Comparison of doses to $\mathrm{NpO}_{2}$ samples using $500 \mathrm{ppm}^{238} \mathrm{Pu}$ and $7000 \mathrm{ppm}{ }^{244} \mathrm{Cm} \ldots \ldots \ldots 12$

3.9 Sample container and pressure transducer used in the alpha radiolysis experiments.. $\ldots \ldots 13$

4.1 Moisture uptake data for $\mathrm{NpO}_{2}$ prepared at $650^{\circ} \mathrm{C} \ldots \ldots \ldots \ldots \ldots \ldots \ldots \ldots \ldots \ldots$

4.2 Pressure and gas yield as a function of dose for sample ${ }^{60} \mathrm{Co} \mathrm{Np}$ Tube 1

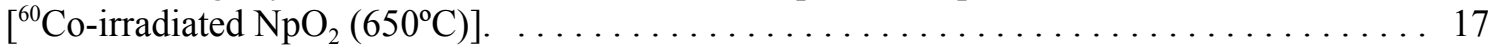

4.3 Pressure and gas yield as a function of dose for sample ${ }^{60} \mathrm{Co}$ Np Tube 2

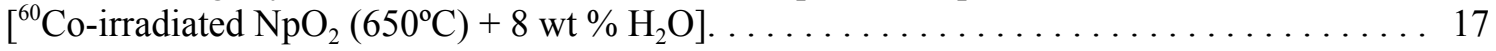

4.4 Pressure and gas yield as a function of dose for sample ${ }^{60} \mathrm{Co} \mathrm{Np}$ Tube 3

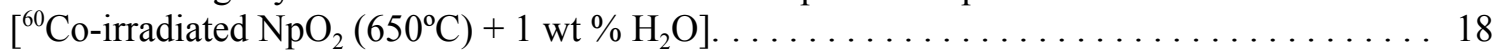

4.5 Pressure and gas yield as a function of dose for sample ${ }^{60} \mathrm{Co} \mathrm{Np}$ Tube 4

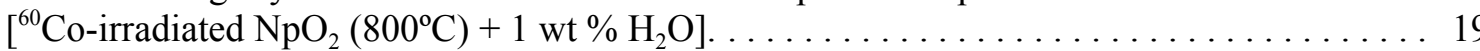




\section{LIST OF FIGURES (continued)}

4.6 Pressure and gas yield as a function of dose for sample HFIR Np Tube 1

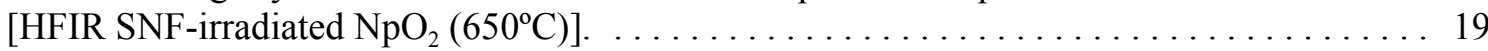

4.7 Pressure and gas yield as a function of dose for sample HFIR Np Tube 2

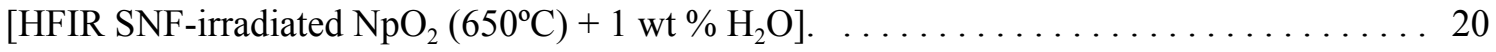

4.8 Pressure and gas yield as a function of dose for sample HFIR Np Tube 3

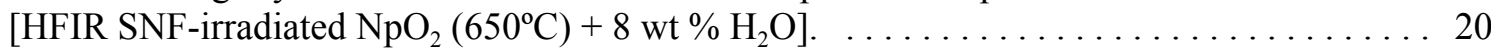

4.9 Pressure and gas yield as a function of dose for sample HFIR Np Tube 4

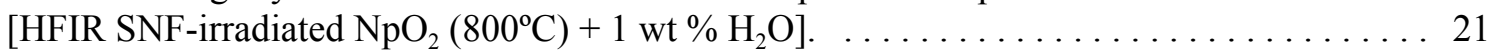

4.10 Pressure and gas yield as a function of dose for sample Alpha Np Tube 1

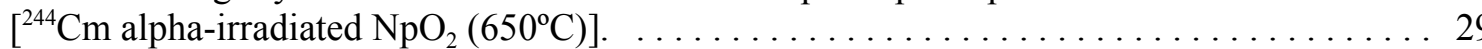

4.11 Pressure and gas yield as a function of dose for sample Alpha $\mathrm{Np}$ Tube 2

$\left[{ }^{244} \mathrm{Cm}\right.$ alpha-irradiated $\left.\mathrm{NpO}_{2}\left(650^{\circ} \mathrm{C}\right)+1 \mathrm{wt} \% \mathrm{H}_{2} \mathrm{O}\right]$.

4.12 Pressure and gas yield as a function of dose for sample Alpha $\mathrm{Np}$ Tube 3

$\left[{ }^{244} \mathrm{Cm}\right.$ alpha-irradiated $\mathrm{NpO}_{2}\left(650^{\circ} \mathrm{C}\right)+8$ wt $\left.\% \mathrm{H}_{2} \mathrm{O}\right]$.

4.13 Pressure and gas yield as a function of dose for sample Alpha Np Tube 4

$\left[{ }^{244} \mathrm{Cm}\right.$ alpha-irradiated $\left.\mathrm{NpO}_{2}\left(800^{\circ} \mathrm{C}\right)+1 \mathrm{wt} \% \mathrm{H}_{2} \mathrm{O}\right]$.

4.14 Pressure and gas yield as a function of dose for sample Alpha Np Tube 5

$\left[{ }^{244} \mathrm{Cm}\right.$ alpha-irradiated $\left.\mathrm{NpO}_{2}\left(650^{\circ} \mathrm{C}\right)+0.5 \mathrm{wt} \% \mathrm{H}_{2} \mathrm{O}\right]$. 


\section{LIST OF TABLES}

Table

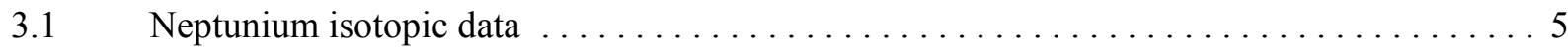

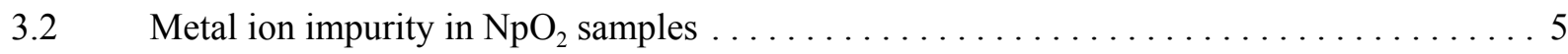

Constant humidity control using sulfuric acid solutions $\ldots \ldots \ldots \ldots \ldots \ldots \ldots \ldots$

3.4 Volume of sample containers used in irradiation experiments $\ldots \ldots \ldots \ldots \ldots \ldots$

3.5 Example of radionuclide composition and dose contribution data for a $\mathrm{NpO}_{2}$

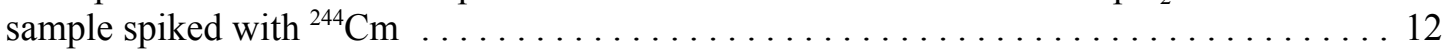

4.1 Summary of gamma irradiation experiments performed $\ldots \ldots \ldots \ldots \ldots \ldots \ldots$

4.2 Results of mass spectrometric analysis of gas composition from

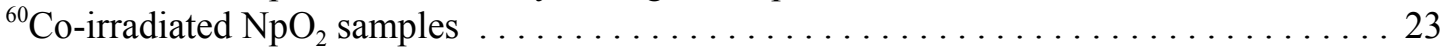

4.3 Results of mass spectrometric analysis of gas composition from

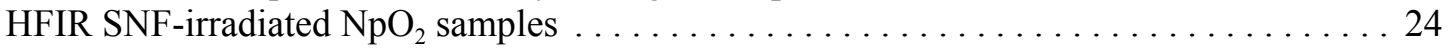

4.4 Estimated change in gas composition for selected experiments as a result of radiolysis . . 25

4.5 Estimated $\mathrm{H}_{2}$ production as a percentage of initial amount of water available for

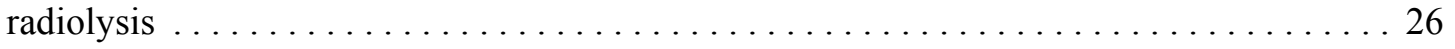

4.6 Summary of alpha irradiation experiments performed $\ldots \ldots \ldots \ldots \ldots \ldots \ldots \ldots 27$

4.7 Results of mass spectrometric analysis of gas composition from

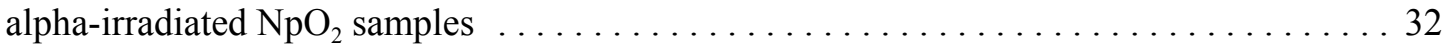





\section{ACRONYMS, ABBREVIATIONS, AND DEFINITIONS}

$\begin{array}{ll}\text { ATR } & \text { Advanced Test Reactor } \\ \text { DOE } & \text { U.S. Department of Energy } \\ \text { G-value } & \begin{array}{l}\text { the number of molecules of gas either produced or destroyed per } 100 \mathrm{eV} \text { of energy } \\ \text { deposited in the sample }\end{array} \\ \text { HEPA } & \text { high-efficiency particulate air (filter) } \\ \text { HFIR } & \text { High Flux Isotope Reactor } \\ \text { INEEL } & \text { Idaho National Engineering and Environmental Laboratory } \\ \text { LANL } & \text { Los Alamos National Laboratory } \\ \text { MGy } & \text { megagray, } 1 \text { MGy }=10^{6} \mathrm{~J} / \mathrm{kg}(1 \mathrm{~Gy}=100 \mathrm{rad}) \\ \text { ORNL } & \text { Oak Ridge National Laboratory } \\ \text { PCV } & \text { primary containment vessel } \\ \text { REDC } & \text { Radiochemical Engineering Development Center } \\ \text { SNF } & \text { spent nuclear fuel } \\ \text { SRS } & \text { Savannah River Site }\end{array}$





\begin{abstract}
Plans are to convert the ${ }^{237} \mathrm{~Np}$ that is currently stored as a nitrate solution at the Savannah River Site to $\mathrm{NpO}_{2}$ and then ship it to the Y-12 National Security Complex in Oak Ridge for interim storage. This material will serve as feedstock for the ${ }^{238} \mathrm{Pu}$ production program, and some will be periodically shipped to the Oak Ridge National Laboratory (ORNL) for fabrication into targets. The safe storage of this material requires an understanding of the radiolysis of moisture that is sorbed on the oxides, which, in turn, provides a basis for storage criteria (namely, moisture content). A two-component experimental program has been undertaken at ORNL to evaluate the radiolytic effects on $\mathrm{NpO}_{2}$ : (1) moisture uptake experiments and (2) radiolysis experiments using both gamma and alpha radiation.

These experiments have produced two key results. First, the water uptake experiments demonstrated that the $0.5 \mathrm{wt} \%$ moisture limit that has been typically established for similar materials (e.g., uranium and plutonium oxides) cannot be obtained in a practical environment. In fact, the uptake in a typical environment can be expected to be at least an order of magnitude lower than the limit.

The second key result is the establishment of steady-state pressure plateaus as a result of the radiolysis of sorbed moisture. These plateaus are the result of back reactions that limit the overall pressure increase and $\mathrm{H}_{2}$ production. These results clearly demonstrate that $0.5 \mathrm{wt} \% \mathrm{H}_{2} \mathrm{O}$ on $\mathrm{NpO}_{2}$ is safe for long-term storage-if such a moisture content could even be practically reached.
\end{abstract}





\section{INTRODUCTION}

The Department of Energy (DOE) Office of Space and Defense Power, NE-50, is reestablishing domestic production of ${ }^{238} \mathrm{Pu}$ using existing DOE facilities. The feed material for the production is ${ }^{237} \mathrm{~Np}$, which is currently stored at the Savannah River Site (SRS). This material will be stabilized as an oxide, packaged, and then transported to the Y-12 National Security Complex for interim storage. Y-12 will then transfer material as needed to Oak Ridge National Laboratory (ORNL). Target fabrication will occur at the Radiochemical Engineering Development Center (REDC) Building 7930. The High Flux Isotope Reactor (HFIR) at ORNL and the Advanced Test Reactor (ATR) at the Idaho National Engineering and Environmental Laboratory (INEEL) will be used to irradiate ${ }^{237} \mathrm{~Np}$-containing targets to produce ${ }^{238} \mathrm{Pu}$. The irradiated targets will undergo chemical processing at the REDC to (1) recover ${ }^{238} \mathrm{Pu}$ for shipment to Los Alamos National Laboratory (LANL) and (2) recover ${ }^{237} \mathrm{~Np}$ for recycle.

Safety issues concerning transportation and long-term storage of neptunium are of a particular concern to the program. The material and its packaging must comply with shipping standards as well as provide for safe storage.

One aspect relative to the safe transport and storage of $\mathrm{NpO}_{2}$ is radiolysis of sorbed water. Current safety analyses assume that all of the water absorbed on the surface of the $\mathrm{NpO}_{2}$ can be radiolyzed to gaseous hydrogen and oxygen, thus generating significant gas pressures within the storage containers. Also, the potential for detonation of the hydrogen has been identified as a safety issue for transportation. However, experimental work by Icenhour et al. ${ }^{1-4}$ using uranium oxides and uranium oxyfluorides has demonstrated that radiolysis does not convert all of the water to $\mathrm{H}_{2}$ and $\mathrm{O}_{2}$ because of competing back reactions that result in a pressure plateau, demonstrating that a steady state has been reached. In some cases, the vessel actually goes to vacuum conditions as a result of the dominance of back reactions.

The use of high-dose-rate gamma and/or alpha irradiation capable of radiolyzing significant quantities of the proposed materials in a short period of time is the only practical way to achieve the necessary doses and thus assess potential long-term storage problems. A set of experiments was performed to irradiate $\mathrm{NpO}_{2}$ samples that have sorbed moisture. This report provides a description of the experiments and the results. 


\section{BACKGROUND}

The neptunium to be used as feed material currently exists in a nitrate solution in the SRS H-Canyon. The neptunium solution, which contains about $500 \mathrm{ppm}{ }^{238} \mathrm{Pu},{ }^{5}$ will undergo chemical processing in a glove-box line (HB-Line Phase II) to remove impurities and convert it to an oxide as depicted in Fig. 2.1.

The neptunium solution first undergoes a feed adjustment to 6-8 $M \mathrm{HNO}_{3}$. The adjusted solution is then fed into anion-exchange columns, where the neptunium nitrate complex absorbs, allowing most metal impurities to pass through the column. Next, a decontamination wash is performed to remove residual impurities. Finally, a weak nitric acid solution is passed through the column to elute the neptunium.

Once the anion-exchange process has been completed, the resulting neptunium solution is combined with oxalic acid, which forms an insoluble neptunium oxalic precipitant. This product is filtered, and the neptunium oxalate is then calcined at $\sim 600^{\circ} \mathrm{C}$ to convert the oxalate to oxide.

The oxide will be packaged in a can-bag-can configuration for shipment (Fig. 2.1). The inner can, which contains up to $6 \mathrm{~kg}$ neptunium, is a screw-top, food-pack convenience can. Because no gasket or sealing compounds are used on the closure, this inner can will not be gastight. The inner can is contained in a heat-sealed polyethylene bag, which has an installed HEPA (high-efficiency particulate air) filter. The can-bag will then be placed inside an outer can, which has a HEPA filter in its lid. ${ }^{*}$ Finally, the can-bag-can will be placed inside a 9975 primary containment vessel (PCV). ${ }^{6}$ SRS currently plans to evacuate the PCV and backfill with argon. Because of the installed HEPA filters and the screw-top lid on the inner can, the entire contents of the PCV will be evacuated and backfilled. This operation is expected to reduce the $\mathrm{O}_{2}$ concentration inside the PCV to less than 5 vol \%.

Concerns related to the long-term storage of the $\mathrm{NpO}_{2}$ are the potential for container pressurization and/or the formation of $\mathrm{H}_{2}$ as a result of radiolytic decomposition of moisture that is sorbed on the oxide. To address these concerns, $\mathrm{NpO}_{2}$ radiolysis experiments have been conducted at ORNL using both gamma and alpha radiation sources. Samples of $\mathrm{NpO}_{2}$ were prepared by the method expected to be used at SRS (i.e., oxalate precipitation and calcination). Moisture was added to the samples to simulate water uptake.

The equipment and experimental facilities described in this report have been used in similar studies concerning gamma irradiation of uranium oxides and fluoride salts with various amounts of sorbed water. $^{1-4}$

*Because of ergonomic considerations, two bagged inner cans may be used instead of just one. 


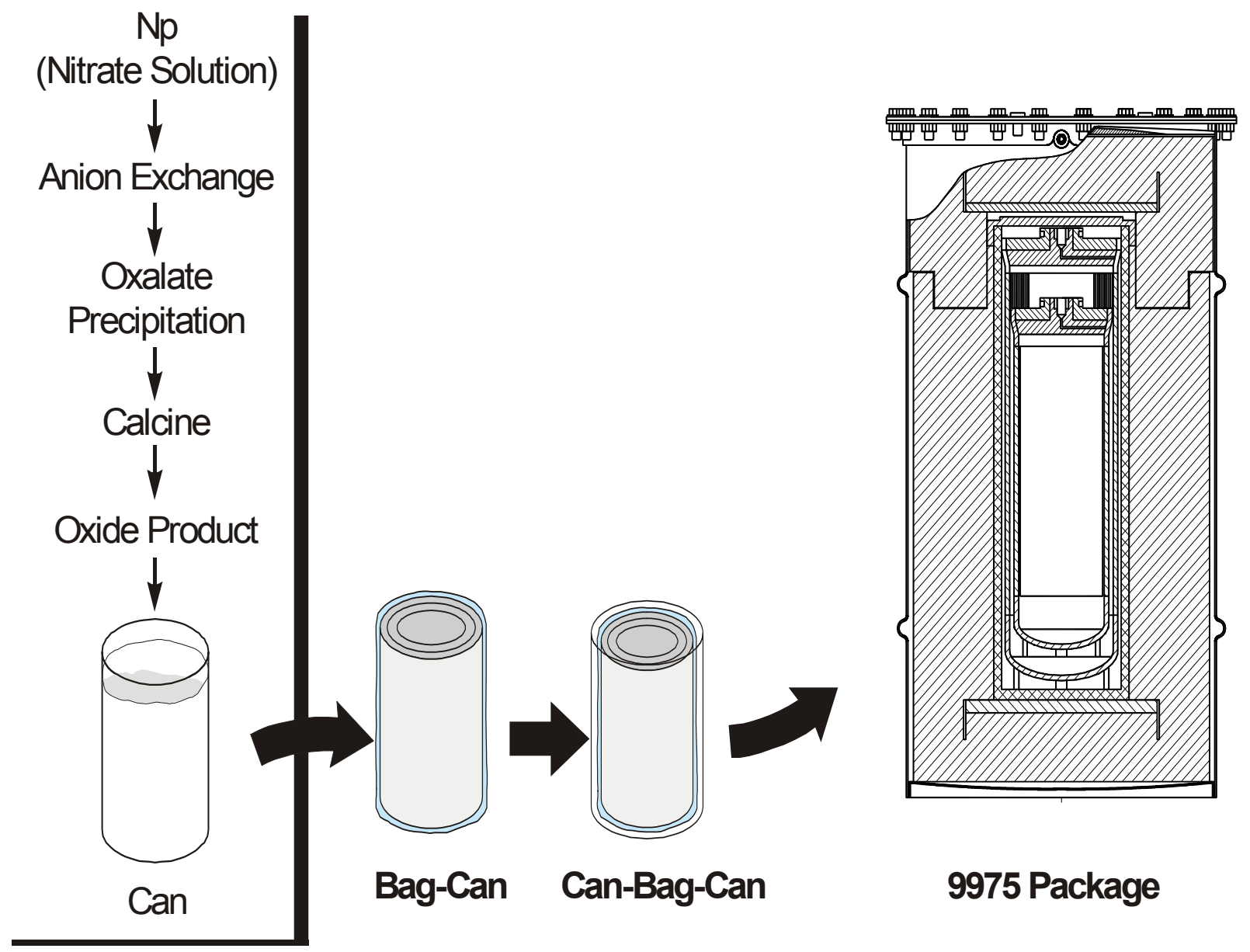

Confinement Barrier

Fig. 2.1. Schematic depiction of neptunium processing and packaging. 


\section{EXPERIMENTAL}

The experimental program was divided into three distinct activities: sample preparation, water sorption studies, and radiolysis experiments.

\subsection{SAMPLE PREPARATION}

Twelve samples of $\mathrm{NpO}_{2}$ were prepared and then irradiated to evaluate radiolytic decomposition of water. The samples first underwent chemical processing at REDC Building 7930 to prepare the $\mathrm{NpO}_{2}$ in a form similar to that expected from SRS. ${ }^{7}$ The water content and the surface area of the samples were varied for the experiments.

In order to prepare $\mathrm{NpO}_{2}$ for these experiments, a batch of $80-100 \mathrm{~g}$ of $\mathrm{NpO}_{2}$ was dissolved in nitric acid. Some of the feed material was neptunium oxide originally obtained from LANL. The majority of the material had been processed using hydroxide precipitation, oxalate precipitation, and ion-exchange processing at the REDC. Because the neptunium product batches from the hydroxide precipitation and oxalate precipitation processes were calcined at $1400^{\circ} \mathrm{C}$, they were extremely difficult to dissolve. Therefore, these various sources of neptunium were dissolved in $8 M \mathrm{HNO}_{3}$ acid with $0.02 M \mathrm{NaF}$ added to the solution, followed by heating over a period of about $24 \mathrm{~h}$ to promote the dissolution. After dissolution, the neptunium was adjusted to the $4+$ valence state by addition of hydrazine followed by ascorbic acid. A slight excess of oxalic acid was then added to precipitate the neptunium as neptunium oxalate. The resulting material was filtered, dried, and fired to $650^{\circ} \mathrm{C}$ to convert the oxalate to oxide. Some material was fired at $800^{\circ} \mathrm{C}$ to change the surface area. Tables 3.1 and 3.2 provide isotopic and chemical impurity results, respectively, from the analysis of $\mathrm{NpO}_{2}$ prepared by the method described.

\subsection{WATER SORPTION STUDIES}

Neptunium oxide with varying amounts of sorbed water was needed for these experiments. The amount of water sorbed as a function of time was determined by placing these materials in a controlledhumidity environment. Humidities of 60 and $97.5 \%$ were used. The humidity was controlled by

\footnotetext{
*Note that at the time of this work, the exact calcination temperature had not yet been established. It is now expected that the SRS material will be fired at temperatures between 600 and $650^{\circ} \mathrm{C}$, depending on the capability of the furnace used. This temperature range will have no effect on the results or conclusions described in this report.
} 
Table 3.1. Neptunium isotopic data

\begin{tabular}{lc}
\hline & Isotopic abundance (wt \%) \\
\hline${ }^{237} \mathrm{~Np}$ & 99.97361 \\
${ }^{239 / 240} \mathrm{Pu}$ & 0.02558 \\
${ }^{238} \mathrm{Pu}$ & 0.0008 \\
\hline
\end{tabular}

Table 3.2. Metal ion impurity in $\mathrm{NpO}_{2}$ samples

\begin{tabular}{ll}
\hline Element & \multicolumn{1}{c}{ Concentration $(\mathrm{Fg} / \mathrm{g})$} \\
\hline $\mathrm{Al}$ & $1.38 \times 10^{4} \pm 1.38 \times 10^{3}$ \\
$\mathrm{~B}$ & $9.19 \times 10^{3} \pm 9.19 \times 10^{2}$ \\
$\mathrm{Ba}$ & $6.03 \times 10^{3} \pm 6.03 \times 10^{2}$ \\
$\mathrm{Be}$ & $4.25 \times 10^{1} \pm 4.25$ \\
$\mathrm{Ca}$ & $1.94 \times 10^{4} \pm 1.91 \times 10^{3}$ \\
$\mathrm{Cu}$ & $6.79 \times 10^{2} \pm 8.49 \times 10^{1}$ \\
$\mathrm{Fe}$ & $6.52 \times 10^{3} \pm 1.36 \times 10^{3}$ \\
$\mathrm{~K}$ & $8.43 \times 10^{3} \pm 2.08 \times 10^{3}$ \\
$\mathrm{Mg}$ & $1.41 \times 10^{4} \pm 1.31 \times 10^{3}$ \\
$\mathrm{Mn}$ & $2.34 \times 10^{2} \pm 4.25 \times 10^{1}$ \\
$\mathrm{Na}$ & $5.44 \times 10^{4} \pm 5.44 \times 10^{3}$ \\
$\mathrm{Sb}$ & $3.27 \times 10^{3} \pm 7.22 \times 10^{2}$ \\
$\mathrm{Sr}$ & $3.40 \times 10^{2} \pm 3.40 \times 10^{1}$ \\
\hline
\end{tabular}


placing the $\mathrm{NpO}_{2}$ sample in a small open glass container, which, in turn, was placed in a glass desiccator. The desiccant had been removed and was replaced with a small open container of dilute sulfuric acid to yield the desired humidity. The $\mathrm{NpO}_{2}$ samples were periodically removed from the chamber and weighed to determine the uptake of water. Table 3.3 provides relative humidity data for a number of sulfuric acid solutions. (The vapor referred to is pure water.)

Table 3.3. Constant humidity control using sulfuric acid solutions ${ }^{a}$

\begin{tabular}{ccc}
\hline $\begin{array}{c}\text { Density of aqueous } \\
\mathrm{H}_{2} \mathrm{SO}_{4} \text { solution }\end{array}$ & $\begin{array}{c}\text { Relative humidity } \\
(\%)\end{array}$ & $\begin{array}{c}\text { Water vapor pressure at } \\
20^{\circ} \mathrm{C}(\mathrm{mm} \mathrm{Hg})\end{array}$ \\
\hline 1.00 & 100.0 & 17.4 \\
1.05 & 97.5 & 17.0 \\
1.10 & 93.9 & 16.3 \\
1.15 & 88.8 & 15.4 \\
1.20 & 80.5 & 14.0 \\
1.25 & 70.4 & 12.2 \\
1.30 & 58.3 & 10.1 \\
1.35 & 47.2 & 8.3 \\
1.40 & 37.1 & 6.5 \\
1.50 & 18.8 & 3.3 \\
1.60 & 8.5 & 1.5 \\
1.70 & 3.2 & 0.6 \\
\hline
\end{tabular}

${ }^{a}$ From Handbook of Chemistry and Physics, 41 st ed., Chemical Rubber Publishing Co., Cleveland, 1959, p. 2500.

\subsection{RADIOLYSIS EXPERIMENTS}

Radiolysis experiments were performed using both gamma and alpha radiation. The equipment used for these experiments is described in Sects. 3.3.1 and 3.3.2.

\subsubsection{Gamma Irradiation Experiments}

Two different sources of gamma radiation were used: (1) the ORNL ${ }^{60} \mathrm{Co}$ irradiator and (2) the HFIR spent nuclear fuel (SNF) elements. In preparation of the samples, a calibrated pipette was used to add the desired amount of water. 


\subsubsection{1 ${ }^{60} \mathrm{Co}$ irradiation experiments}

A J. L. Shepherd model 109-68 (serial no. 654) ${ }^{60} \mathrm{Co}$ gamma irradiator (shown in Fig. 3.1), providing a dose rate of about $10^{5} \mathrm{rad} / \mathrm{h}$, was used for the experiments. The sample container itself is shown in Fig. 3.2, while Fig. 3.3 shows the samples installed in the irradiator prior to being lowered into the device. A detailed description of the irradiator and the methods used to calculate the dose to the samples (for both the ${ }^{60}$ Co source and HFIR SNF elements) is provided in Ref. 8 .

The samples to be irradiated were placed in stainless steel containers, each of which had a smalldiameter stainless steel tube connected at one end for pressure sensing and a capped opening at the other end for loading samples. The container was connected by small-diameter tubing to a stainless steel Nupro $^{\circledR}$ valve and an MKS Baratron ${ }^{\circledR}$ pressure transducer (Type 127A). The material to be irradiated was loaded through a stainless steel VCR gland on one end of the container.

Preparation of sample containers for their insertion into the ${ }^{60} \mathrm{Co}$ irradiator consisted of leak checks, volume measurements, and loading of the samples into the containers. As part of their fabrication, the containers were leak checked with air to a pressure of about $6.8 \mathrm{~atm}$ (100 psia).

Just before their use, the containers were leak checked again, using both pressure (typically $\sim 3 \mathrm{~atm}$ ) and vacuum. The volume of the irradiation rig (i.e., the sample container, tubing, valve, and pressure transducer) was measured by expanding helium from a known volume into the rig, observing the pressure change, and applying the ideal gas law. The volume of each of the tubes used in the experiments is presented in Table 3.4 .

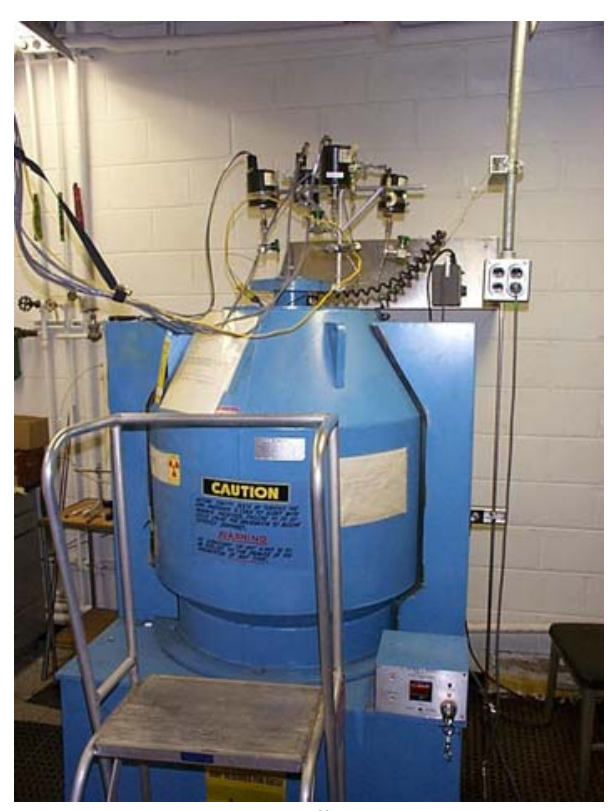

Fig. 3.1. ORNL ${ }^{60} \mathrm{Co}$ irradiator.

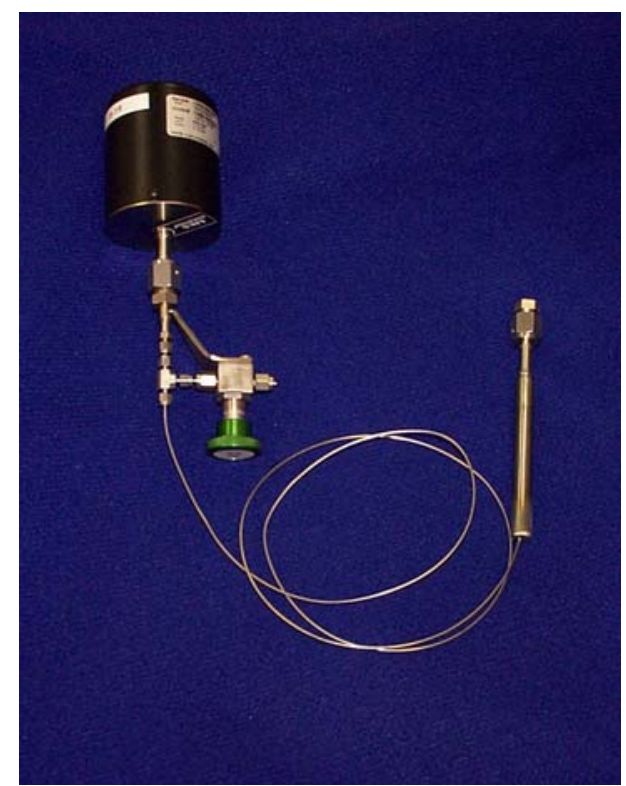

Fig. 3.2. Sample container and pressure transducer used in the ${ }^{60} \mathrm{Co}$ irradiations. 


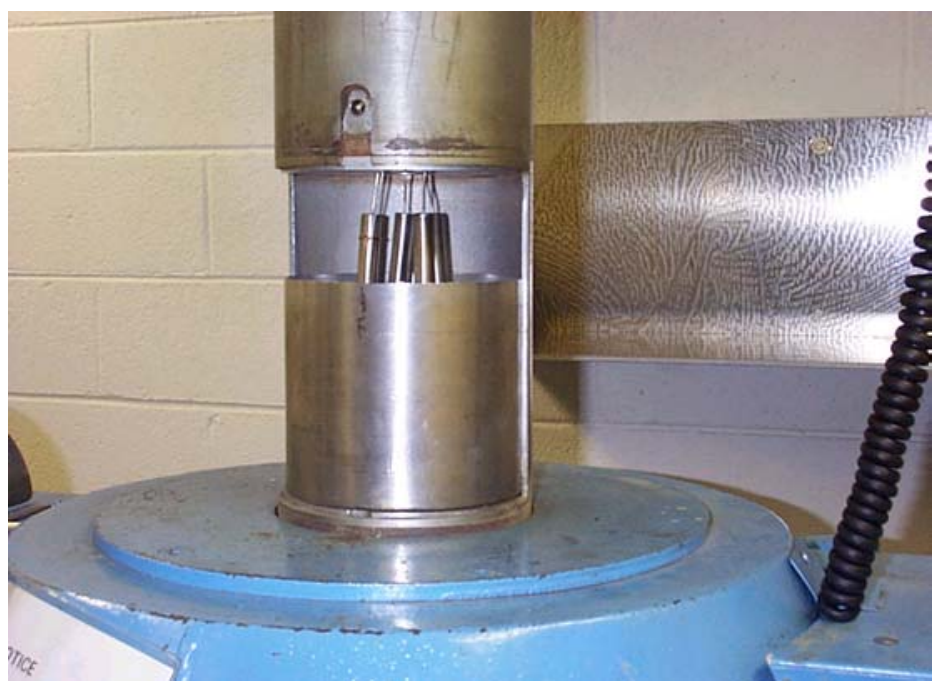

Fig. 3.3. Irradiation chamber of ORNL ${ }^{60} \mathrm{Co}$ irradiator with sample containers installed.

Table 3.4. Volume of sample containers used in irradiation experiments

\begin{tabular}{lc}
\hline Container & Volume $\left(\mathrm{cm}^{3}\right)$ \\
\hline${ }^{60}$ Co Np Tube 1 & 16.7 \\
${ }^{60}$ Co Np Tube 2 & 16.6 \\
${ }^{60}$ Co Np Tube 3 & 16.4 \\
${ }^{60}$ Co Np Tube 4 & 16.1 \\
HFIR Np Tube 1 & 34.6 \\
HFIR Np Tube 2 & 49.7 \\
HFIR Np Tube 3 & 50.8 \\
HFIR Np Tube 4 & 35.4 \\
Alpha Np Tube 1 & 13.1 \\
Alpha Np Tube 2 & 13.3 \\
Alpha Np Tube 3 & 13.5 \\
Alpha Np Tube 4 & 13.7 \\
Alpha Np Tube 5 & 13.1 \\
\hline
\end{tabular}


A computerized data acquisition system was used to collect data during each irradiation. Validyne ${ }^{\circledR}$ hardware and software were used, providing up to eight data channels per card. The data acquisition system is shown in Fig. 3.4. Typical parameters recorded during an irradiation included container pressure, temperature of selected containers, and ambient pressure and temperature.

\subsubsection{HFIR SNF irradiation experiments}

To obtain higher dose rates, the HFIR SNF gamma irradiation facility (shown in Fig. 3.5) was also used. Figure 3.6 depicts the experimental configuration for these irradiations. Samples can be irradiated in the HFIR SNF pool by inserting them into SNF elements. The SNF elements are cylindrical with a hollow center. In its storage position in the SNF pool, a cadmium sleeve inside the hollow region of the element absorbs neutrons. Hence, the hollow region of the fuel element primarily provides a gamma field for irradiation. The neutron flux in this region is about 100 neutrons $\bullet \mathrm{cm}^{Q} \cdot \mathrm{s}^{\mathrm{G}}$. The contribution of neutrons to the radiation damage is negligible when compared with the very large gamma field. Exposure rates vary from about $10^{7}$ to $10^{8} \mathrm{R} / \mathrm{h}$, depending on the time since the discharge of the SNF from the reactor.

A multiple-irradiation container was used for the irradiation of four samples at once (Fig. 3.7). Small sample containers consisting of 1.27-cm-diam stainless steel tubing were placed inside an outer container, which was fabricated from 8.9-cm-diam, 44-cm-long stainless steel pipe. The outer container was closed at one end and had a Conflat flange on the other end. The flange contained five penetrations. Four were used to connect the smaller inner containers to 0.318 -cm-diam stainless steel tubing, while the fifth connected the void volume of the outer container to $0.318-\mathrm{cm}$-diam stainless steel tubing. In each case, this tubing was about $6.1 \mathrm{~m}$ long and was connected to a pressure transducer and to a valve.

The volume of each of the sample containers, which included sampling lines and pressure transducers, is presented in Table 3.4. Before the experiment was transported to the HFIR for insertion in an SNF element, the samples were loaded in air and the outer container was pressurized to $1.7 \mathrm{~atm}$ (10 psig), as required by HFIR operations personnel.

Sensotec $^{\circledR}$ (model FPA, 0-50 psia) pressure transducers were used for the four inner sample containers. A Kobold ${ }^{\circledR}$ (model KPK, 30 in. Hg to 100 psig) compound pressure transducer was used to monitor the pressure in the large outer vessel. A computerized data acquisition system was used to record the pressure throughout the experiments. 

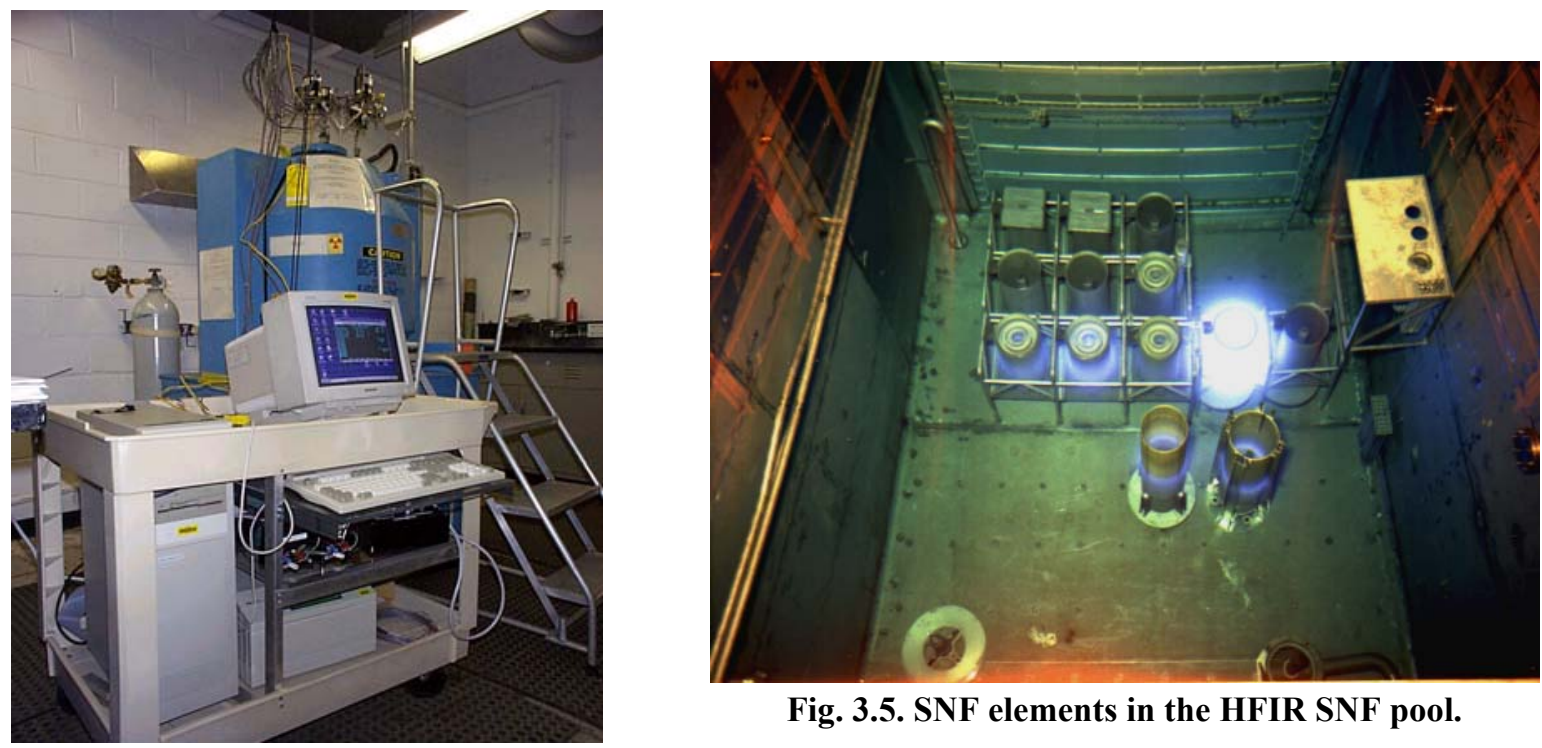

Fig. 3.5. SNF elements in the HFIR SNF pool.

Fig. 3.4. Data acquisition computer in operation at the ORNL ${ }^{60} \mathrm{Co}$ source.

ORNL DWG 99C-487

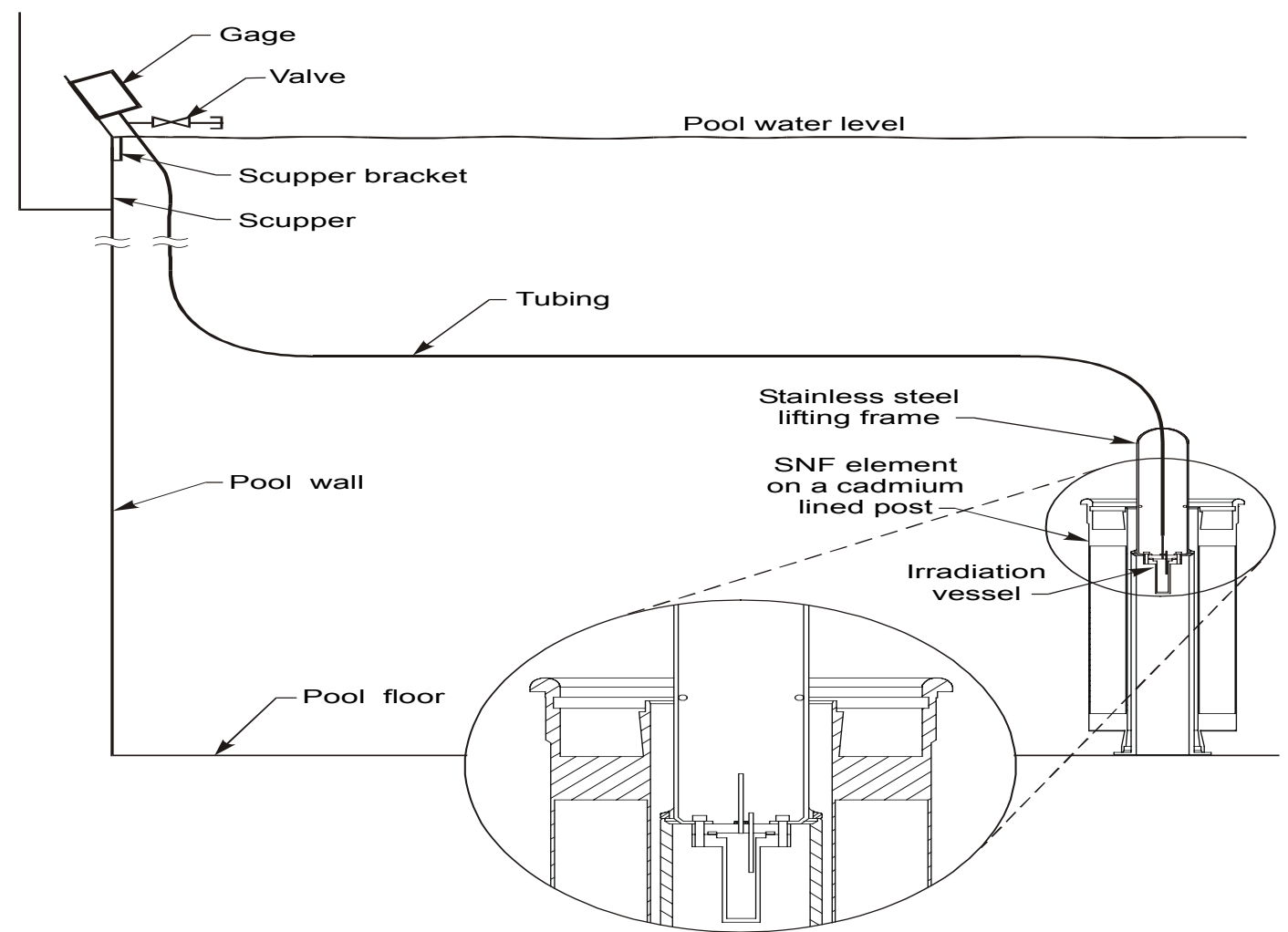

Fig. 3.6. Schematic of the experimental configuration for gamma irradiation experiments with a HFIR SNF element. 


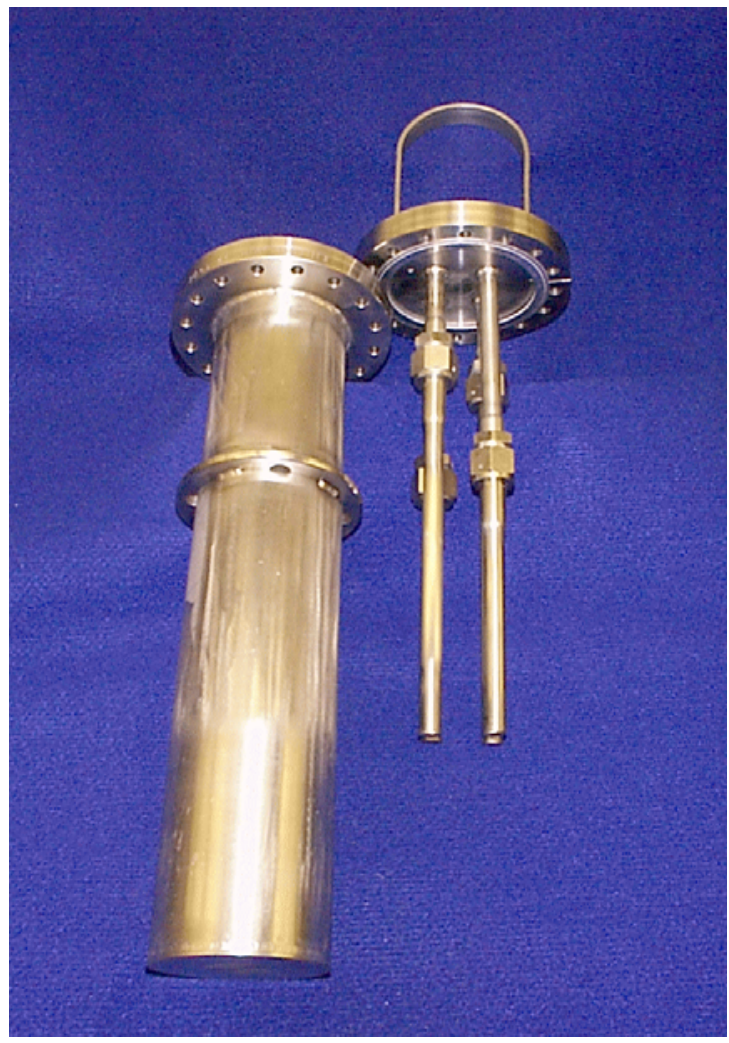

Fig. 3.7. Multiple-irradiation container used in HFIR SNF irradiations.

\subsubsection{Alpha Radiolysis Experiments}

To perform the alpha radiolysis experiments, neptunium samples were spiked with ${ }^{244} \mathrm{Cm}$ to mimic the dose from ${ }^{238} \mathrm{Pu}$, but in a shorter time period reasonable for the present experimental study. Note that the neptunium in storage at SRS contains about $500 \mathrm{ppm}{ }^{238} \mathrm{Pu}$. Samples of $\mathrm{NpO}_{2}$ containing about $7000 \mathrm{ppm}{ }^{244} \mathrm{Cm}$ realized a dose rate about 70 times that for the SRS material, as illustrated in Figure 3.8. An example of the radionuclide composition and dose contribution data for the curium used is presented in Table 3.5. This table demonstrates that while $40 \mathrm{wt} \%$ of the material used to spike the samples was ${ }^{240} \mathrm{Pu}$, more than $99 \%$ of the dose was delivered by the parent isotope, ${ }^{244} \mathrm{Cm}$.

A portion of the dissolved neptunium was set aside for alpha radiolysis experiments. The neptunium was adjusted to the $4+$ valence state and diluted to $1-2 M \mathrm{HNO}_{3}$. A small aliquot of ${ }^{244} \mathrm{Cm}$ was then mixed with the neptunium solution, and oxalic acid was added to form both neptunium and curium oxalate. The oxalate product was filtered, dried, and calcined at $650^{\circ} \mathrm{C}$. The resulting oxide was then divided into four samples, one of which was further heated to $800^{\circ} \mathrm{C}$. 


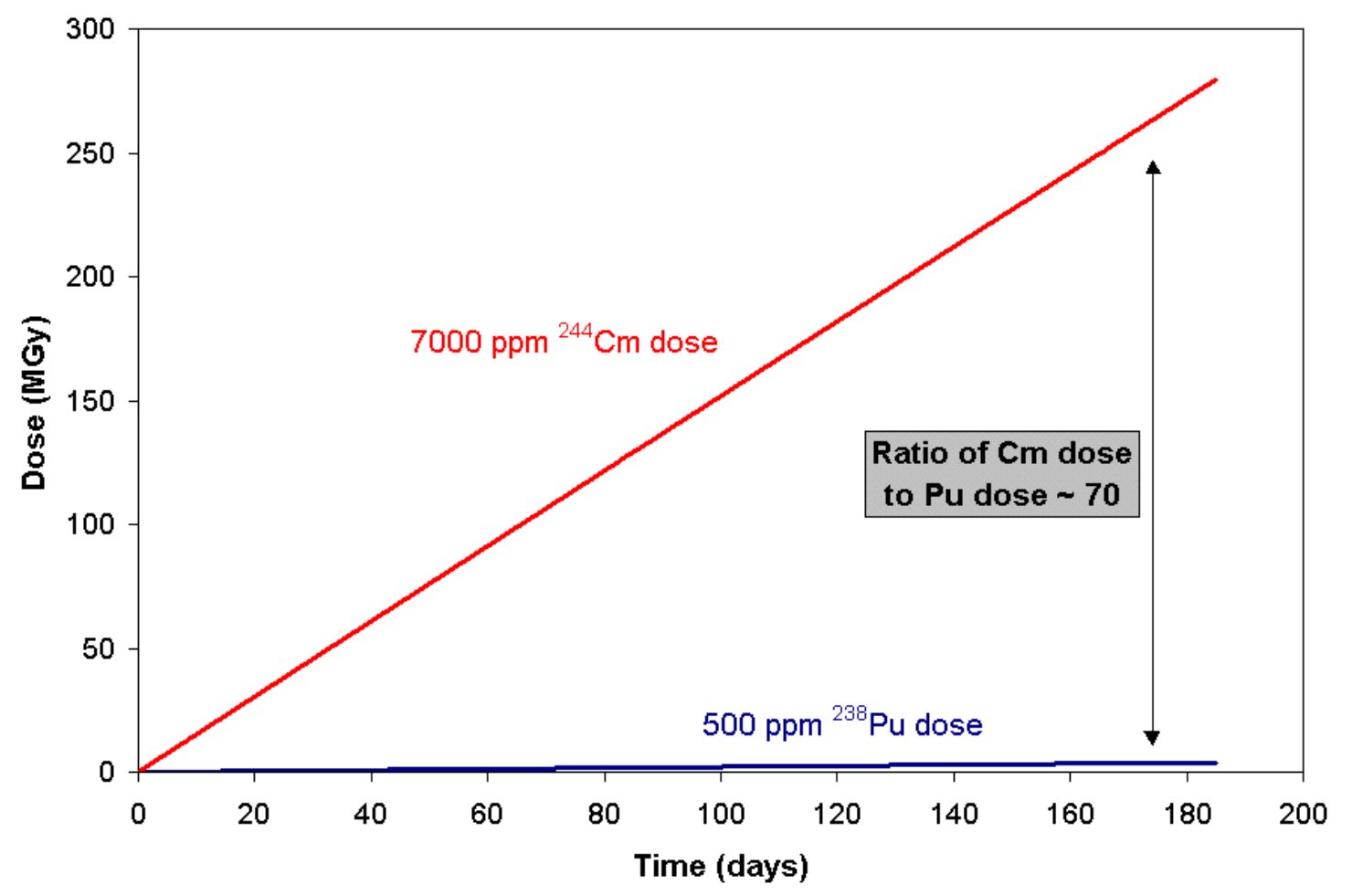

Fig. 3.8. Comparison of doses to $\mathrm{NpO}_{2}$ samples using $500 \mathrm{ppm}{ }^{238} \mathrm{Pu}$ and $7000 \mathrm{ppm}{ }^{244} \mathrm{Cm}$.

Table 3.5. Example of radionuclide composition and dose contribution data for a $\mathrm{NpO}_{2}$ sample spiked with ${ }^{244} \mathrm{Cm}$

\begin{tabular}{cllcll}
\hline Radionuclide & $\begin{array}{l}\text { Half-life } \\
\text { (years) }\end{array}$ & $\begin{array}{l}\text { Specific } \\
\text { activity }(\mathrm{Ci} / \mathrm{g})\end{array}$ & $\begin{array}{l}\text { Average alpha } \\
\text { energy }(\mathrm{MeV})\end{array}$ & $\begin{array}{c}\text { Composition } \\
\text { (wt \%) }\end{array}$ & $\begin{array}{l}\text { Contribution to } \\
\text { dose }(\%)\end{array}$ \\
\hline${ }^{244} \mathrm{Cm}$ & 18.11 & 80.9 & 5.7965 & 50.34 & 99.74 \\
${ }^{245} \mathrm{Cm}$ & 8500 & 0.1717 & 5.363 & 1.36 & 0.01 \\
${ }^{246} \mathrm{Cm}$ & 4730 & 0.3072 & 5.376 & 7.31 & 0.05 \\
${ }^{247} \mathrm{Cm}$ & $1.56 \times 10^{7}$ & $9.20 \times 10^{! 5}$ & 4.9475 & 0.12 & $2.34 \times 10^{! 7}$ \\
${ }^{248} \mathrm{Cm}$ & $3.40 \times 10^{5}$ & 0.00424 & 4.6524 & 0.07 & $5.72 \times 10^{! 6}$ \\
${ }^{240} \mathrm{Pu}$ & 6563 & 0.22696 & 5.1549 & 40.04 & 0.20 \\
${ }^{241} \mathrm{Pu}$ & 14.4 & 103 & 0.000118 & $2.01 \times 10^{! 6}$ & $1.03 \times 10^{! 10}$ \\
${ }^{242} \mathrm{Pu}$ & $3.76 \times 10^{5}$ & 0.003926 & 4.89 & $1.93 \times 10^{! 5}$ & $1.57 \times 10^{! 9}$ \\
${ }^{243} \mathrm{Am}$ & 7380 & 0.1993 & 5.2656 & 0.76 & $3.37 \times 10^{! 3}$ \\
\hline
\end{tabular}


The samples were placed in stainless steel containers, and the desired amount of water was then added. The containers were connected by a small-diameter stainless steel tube to a Sensotec pressure transducer and to a valve (Fig. 3.9). Filter gaskets $(0.5-\mu \mathrm{m}$ sintered frit) were used in the VCR facesealed connections to prevent movement of particles and the spread of contamination. An Omega ${ }^{\circledR}$ Type $\mathrm{K}$ thermocouple was attached to the outside of each sample container. The void volume of the containers was measured by expanding helium from a known volume. (The measured volumes are shown in Table 3.4.) Samples were prepared and loaded into the containers in a glove box.

\subsection{SAMPLING AND ANALYSES}

At the completion of the irradiations, gas samples were withdrawn and analyzed by mass spectrometry.

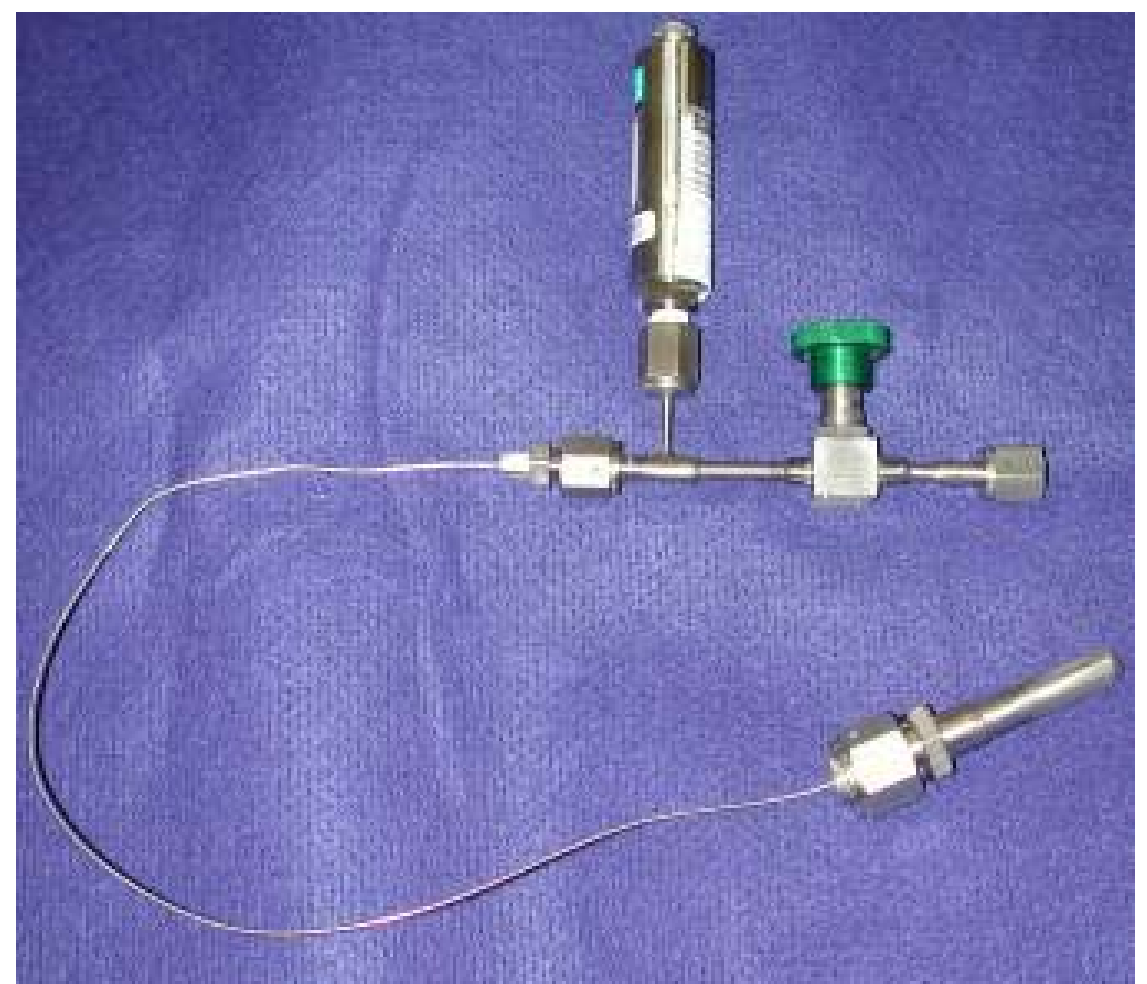

Fig. 3.9. Sample container and pressure transducer used in the alpha radiolysis experiments. 


\section{RESULTS AND DISCUSSION}

\subsection{WATER SORPTION EXPERIMENTS}

The results for the water sorption on the samples prepared at $650^{\circ} \mathrm{C}$ are shown in Fig. 4.1, where the weight gain (i.e., amount of water sorption) of the $\mathrm{NpO}_{2}$ sample is depicted as a function of time for two different relative humidities. The sample exposed to the $97.5 \%$ humidity exhibited an increase in moisture uptake to a limiting value of about $1 \mathrm{wt} \%$. Interestingly, at about 30 days, the lid to the chamber containing the sample was left off, thereby lowering the relative humidity over the sample to that of the glove box. The amount of moisture on the sample rapidly decreased, and, when the lid was replaced, the amount of moisture returned to the previous limit. For the sample exposed to the $60 \%$ humidity, a much lower moisture uptake limit was reached-about $0.02 \mathrm{wt} \%$. A similar behavior was seen for the samples prepared at $800^{\circ} \mathrm{C}$ (not shown in this report). For these samples, the maximum moisture uptake was $0.8 \mathrm{wt} \%$ in the $97.5 \%$ humidity, while the maximum was about $0.02 \mathrm{wt} \%$ in the $60 \%$ humidity.

The water sorption experiments showed that in practical humidities, $\mathrm{NpO}_{2}$ sorbs very little water. Even in the case of extreme humidity (i.e., $97.5 \%$ ), the sample prepared at $650^{\circ} \mathrm{C}$ sorbed quantities of water only up to $\sim 1 \mathrm{wt} \%$ (Fig. 4.1). Furthermore, this water was held very loosely on the surface-as demonstrated by the overnight occurrence described in the paragraph above. However, in the more normal operational case of $60 \%$ relative humidity, the maximum water uptake was about $0.02 \mathrm{wt} \%$.

Taking these results in a broader perspective, it is worth noting that the plutonium and ${ }^{233} \mathrm{U}$ storage standards $\mathrm{s}^{9,10}$ have been set with the maximum acceptable moisture content at $0.5 \mathrm{wt} \%$. With such precedents, we expect an identical limit will be established for the $\mathrm{NpO}_{2}$ that is to be prepared at SRS. In light of the current moisture uptake data for the $\mathrm{NpO}_{2}$ prepared at $650^{\circ} \mathrm{C}$, and based on similar results obtained at $75 \%$ relative humidity by the Savannah River Technology Center, ${ }^{11}$ the storage standard limit of $0.5 \mathrm{wt} \%$ could never be reached in normal operating or storage conditions where humidity levels are controlled at $60-75 \%$.

\subsection{GAMMA RADIOLYSIS EXPERIMENTS}

Irradiation experiments were conducted for a number of $\mathrm{NpO}_{2}$ samples using either the ORNL ${ }^{60} \mathrm{Co}$ source or HFIR SNF elements. Table 4.1 provides a summary of the irradiation experiments performed. The results obtained from these radiolysis experiments are presented in Sects. 4.2.1 and 4.2.2. 

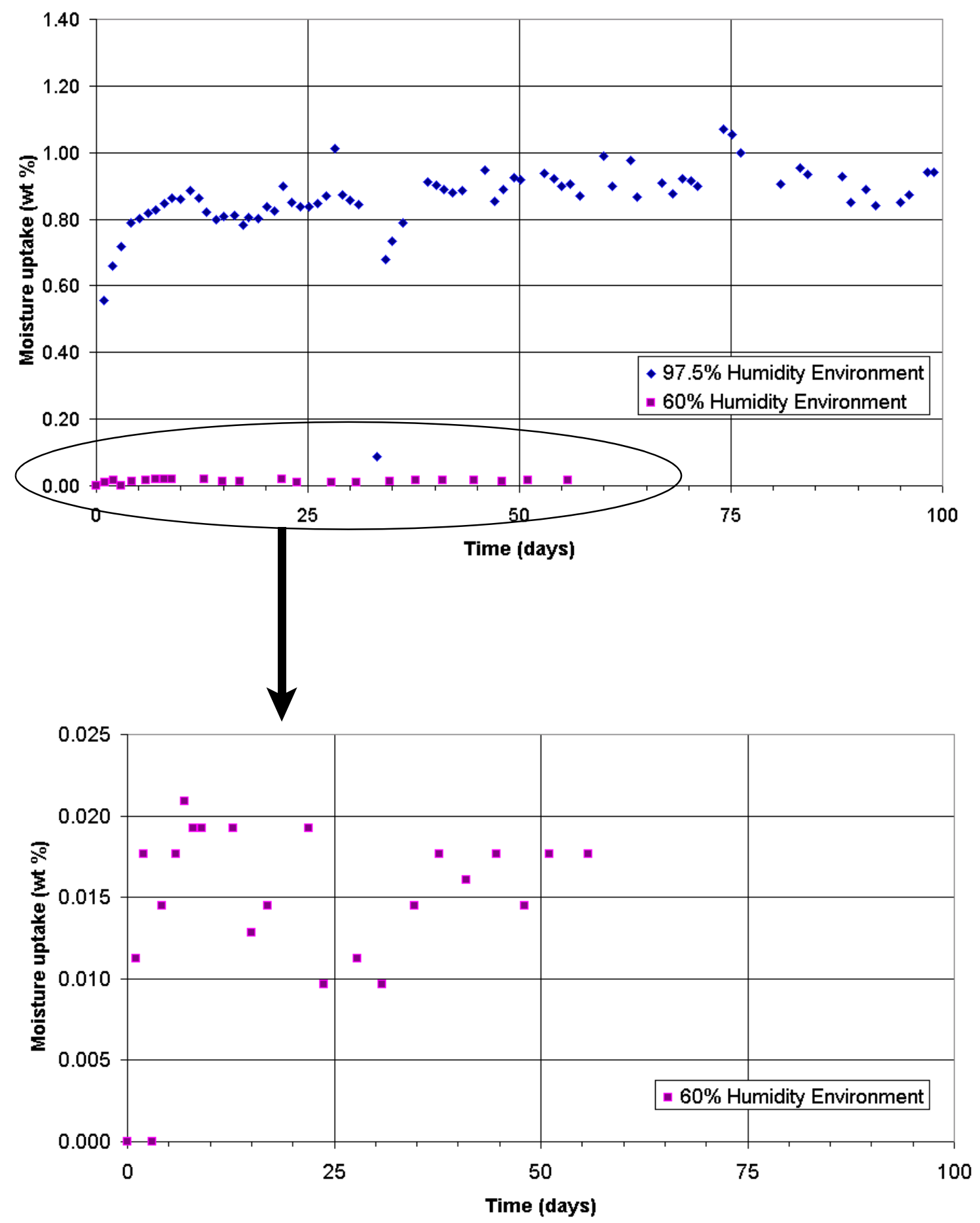

Fig. 4.1. Moisture uptake data for $\mathrm{NpO}_{2}$ prepared at $650^{\circ} \mathrm{C}$. 
Table 4.1. Summary of gamma irradiation experiments performed

\begin{tabular}{|c|c|c|c|}
\hline Experiment & Material $^{a}$ & Mass (g) & Total dose (MGy) \\
\hline${ }^{60} \mathrm{Co} \mathrm{Np}$ Tube 1 & $\mathrm{NpO}_{2}\left(650^{\circ} \mathrm{C}\right)$ & 3.9593 & 4.2 \\
\hline${ }^{60} \mathrm{Co} \mathrm{Np}$ Tube 2 & $\begin{array}{l}\mathrm{NpO}_{2}\left(650^{\circ} \mathrm{C}\right) \\
+8 \mathrm{wt} \% \mathrm{H}_{2} \mathrm{O}\end{array}$ & 4.3152 & 4.1 \\
\hline${ }^{60} \mathrm{Co} \mathrm{Np}$ Tube 3 & $\begin{array}{l}\mathrm{NpO}_{2}\left(650^{\circ} \mathrm{C}\right) \\
+1 \mathrm{wt} \% \mathrm{H}_{2} \mathrm{O}\end{array}$ & 3.9832 & 4.2 \\
\hline${ }^{60} \mathrm{Co} \mathrm{Np}$ Tube 4 & $\begin{array}{l}\mathrm{NpO}_{2}\left(800^{\circ} \mathrm{C}\right) \\
+1 \text { wt } \% \mathrm{H}_{2} \mathrm{O}\end{array}$ & 3.9886 & 4.2 \\
\hline HFIR Np Tube 1 & $\mathrm{NpO}_{2}\left(650^{\circ} \mathrm{C}\right)$ & 3.9530 & 613 \\
\hline HFIR Np Tube 2 & $\begin{array}{l}\mathrm{NpO}_{2}\left(650^{\circ} \mathrm{C}\right) \\
+1 \mathrm{wt} \% \mathrm{H}_{2} \mathrm{O}\end{array}$ & 3.9908 & 612 \\
\hline HFIR Np Tube 3 & $\begin{array}{l}\mathrm{NpO}_{2}\left(650^{\circ} \mathrm{C}\right) \\
+8 \text { wt } \% \mathrm{H}_{2} \mathrm{O}\end{array}$ & 4.2806 & 595 \\
\hline HFIR Np Tube 4 & $\begin{array}{l}\mathrm{NpO}_{2}\left(800^{\circ} \mathrm{C}\right) \\
+1 \mathrm{wt} \% \mathrm{H}_{2} \mathrm{O}\end{array}$ & 4.0227 & 611 \\
\hline
\end{tabular}

${ }^{a}$ Value in parenthesis denotes preparation temperature.

\subsubsection{Pressure Measurements}

Pressure within the sample containers was monitored throughout the irradiations, and the pressure data from each of the gamma radiolysis experiments are shown in Figs. 4.2-4.9. The pressure and gas yield (millimoles of gas per gram of sample) are plotted as a function of dose in each of the figures. The gas yield was calculated using the ideal gas law.

Container temperatures in the ${ }^{60} \mathrm{Co}$ irradiator were measured to be about $28^{\circ} \mathrm{C}$. For the HFIR multiple-vessel irradiations, the temperature was estimated to average about $55^{\circ} \mathrm{C}$, based on earlier experiments. ${ }^{3}$ For this earlier work, the temperature typically ranged from 50 to $60^{\circ} \mathrm{C}$, with several short transients upon insertion of the experiment into a fresh element. The difference in temperature between the ${ }^{60} \mathrm{Co}$ and HFIR irradiations did not appear to have a measurable effect on the irradiation results, other than accounting for the slight pressure differences due to gas expansion. 


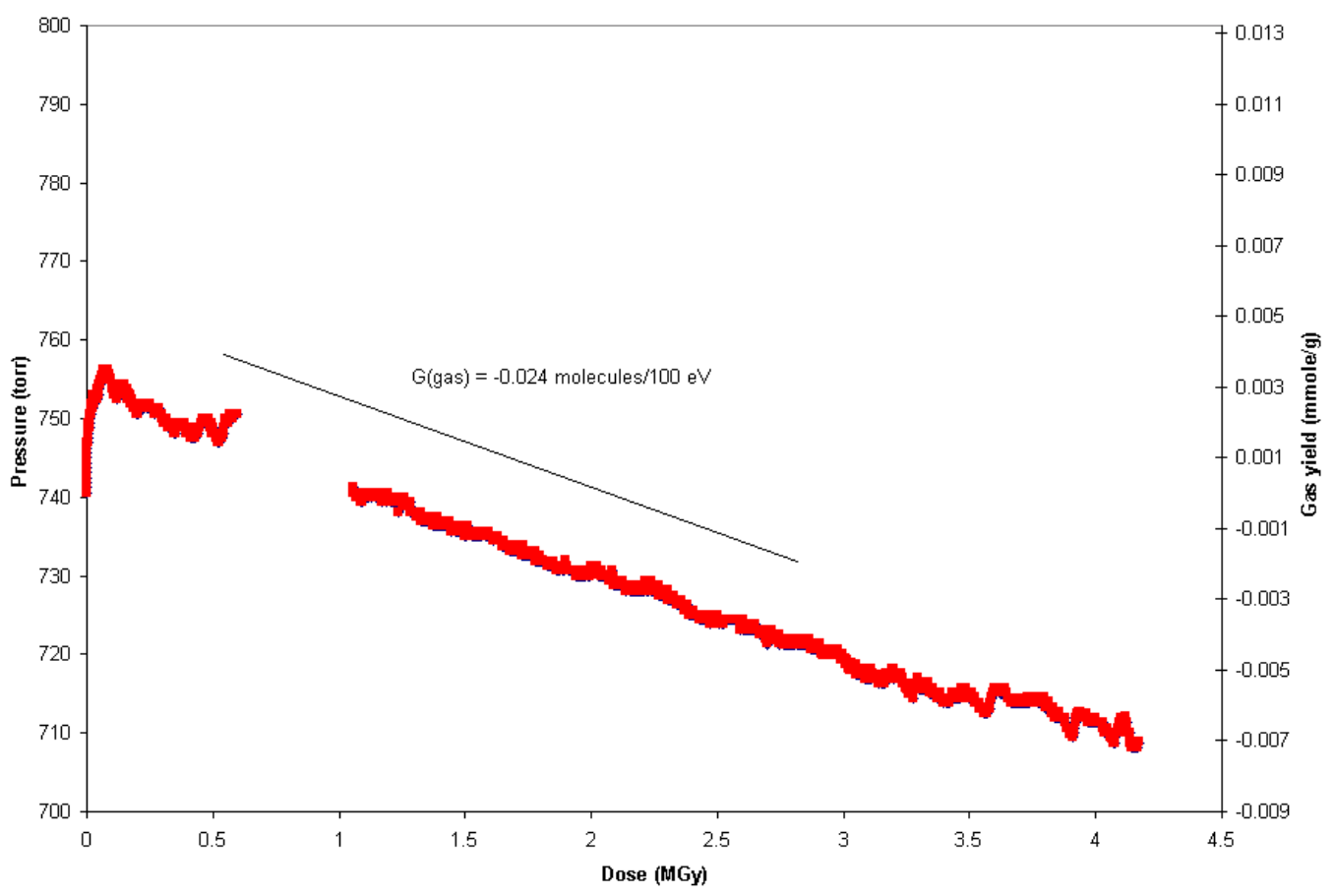

Fig. 4.2. Pressure and gas yield as a function of dose for sample ${ }^{60} \mathrm{Co} \mathrm{Np}$ Tube 1 $\left[{ }^{60} \mathrm{Co}\right.$-irradiated $\left.\mathrm{NpO}_{2}\left(650^{\circ} \mathrm{C}\right)\right]$.

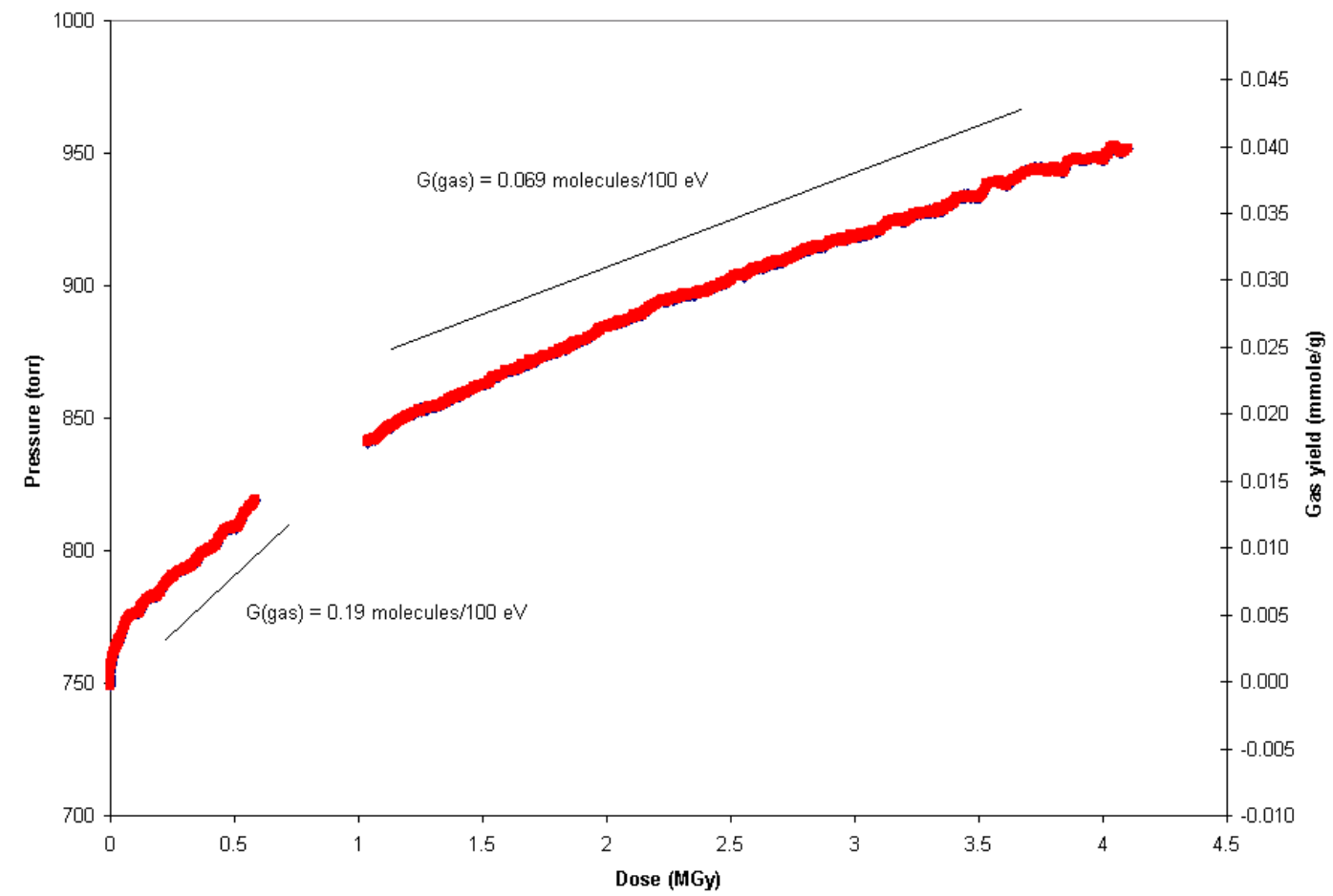

Fig. 4.3. Pressure and gas yield as a function of dose for sample ${ }^{60} \mathrm{Co} \mathrm{Np}$ Tube 2 $\left[{ }^{60} \mathrm{Co}\right.$-irradiated $\left.\mathrm{NpO}_{2}\left(650^{\circ} \mathrm{C}\right)+8 \mathrm{wt} \% \mathrm{H}_{2} \mathrm{O}\right]$. 


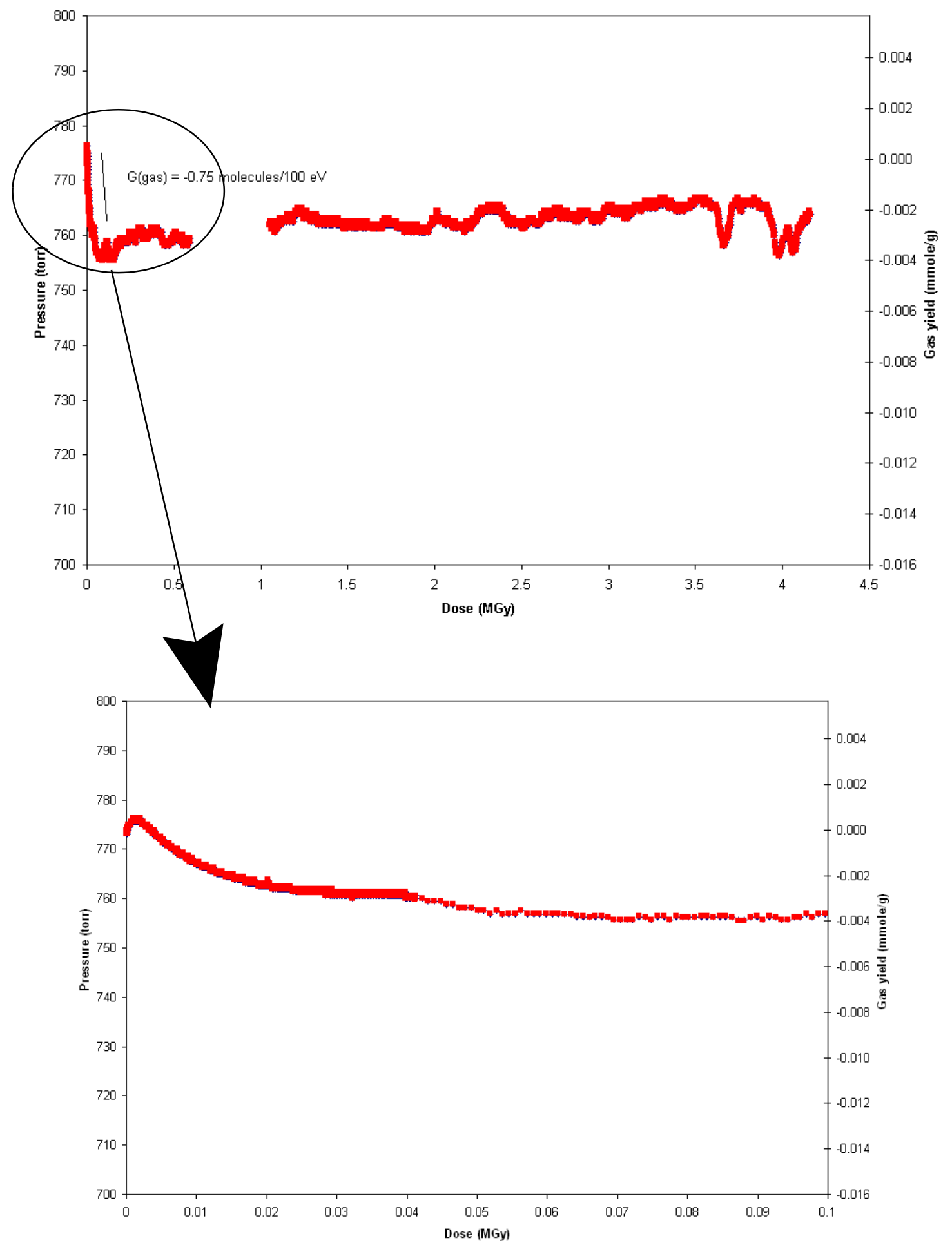

Fig. 4.4. Pressure and gas yield as a function of dose for sample ${ }^{60} \mathrm{Co} \mathrm{Np}$ Tube $3\left[{ }^{60} \mathrm{Co}\right.$-irradiated $\mathrm{NpO}_{2}$ $\left.\left(650^{\circ} \mathrm{C}\right)+1 \mathrm{wt} \% \mathrm{H}_{2} \mathrm{O}\right]$. 


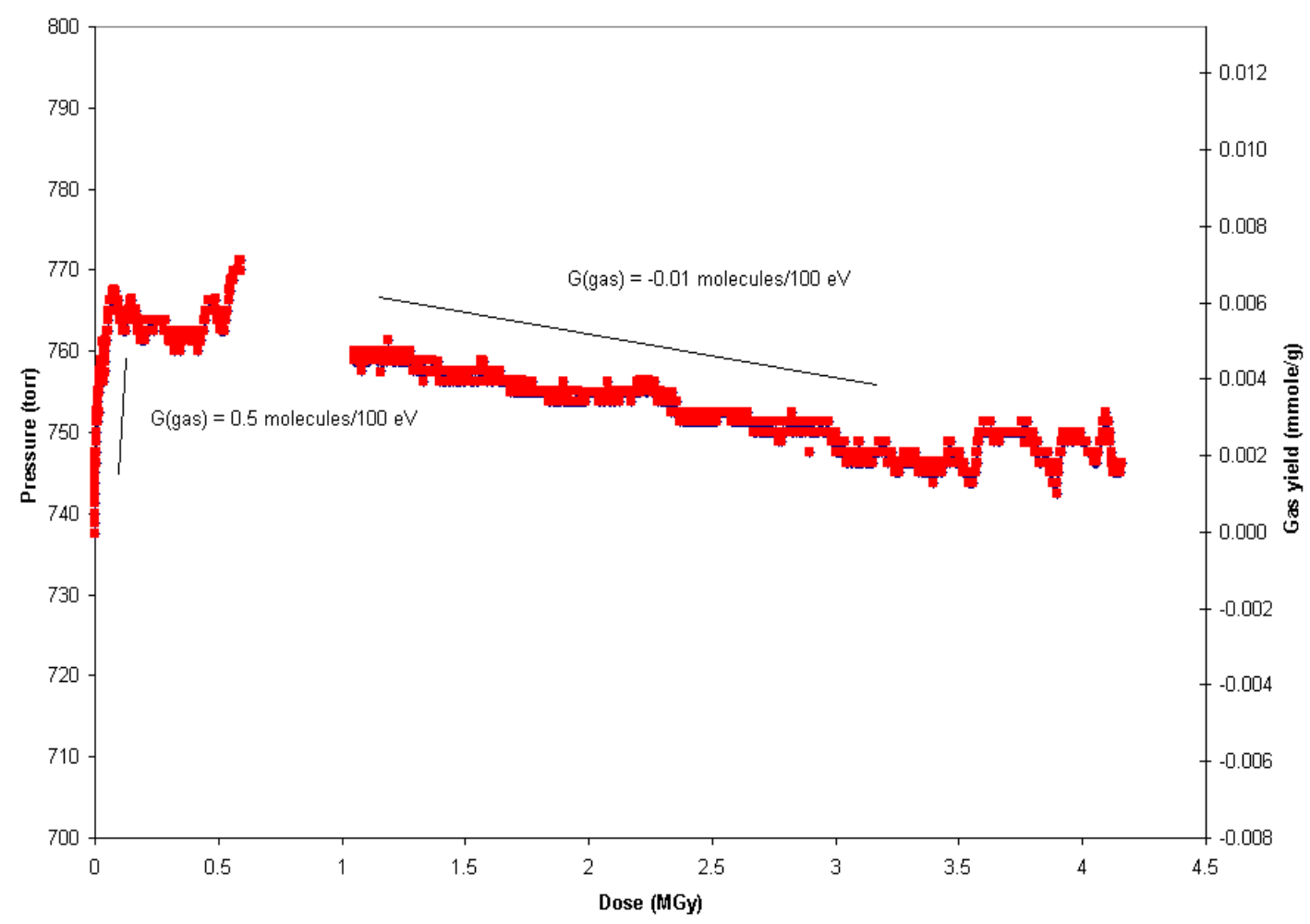

Fig. 4.5. Pressure and gas yield as a function of dose for sample ${ }^{60} \mathrm{Co} \mathrm{Np}$ Tube 4 $\left[{ }^{60} \mathrm{Co}\right.$-irradiated $\left.\mathrm{NpO}_{2}\left(800^{\circ} \mathrm{C}\right)+1 \mathrm{wt} \% \mathrm{H}_{2} \mathrm{O}\right]$.

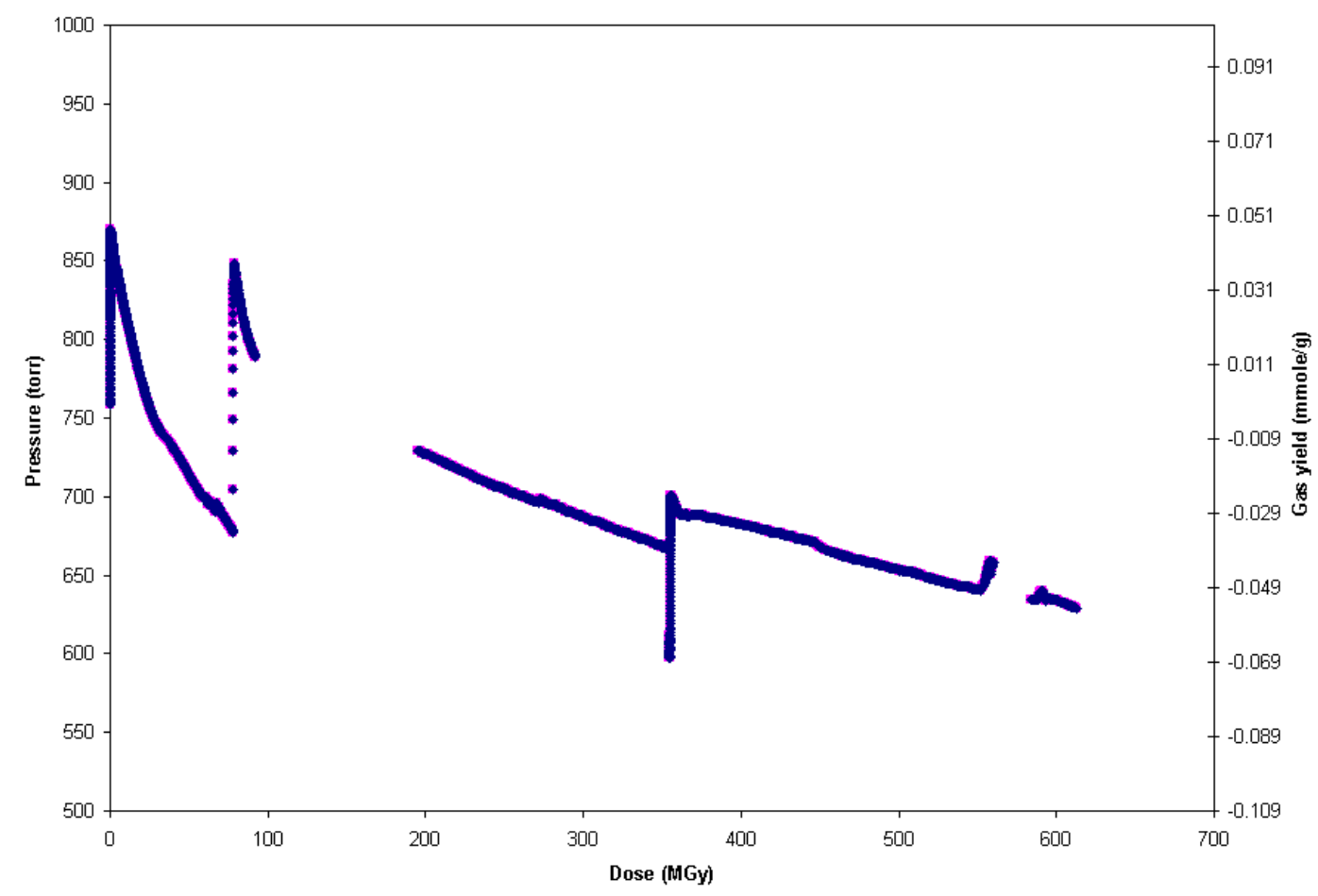

Fig. 4.6. Pressure and gas yield as a function of dose for sample HFIR Np Tube 1 [HFIR SNF-irradiated $\mathrm{NpO}_{2}\left(650^{\circ} \mathrm{C}\right)$ ]. 


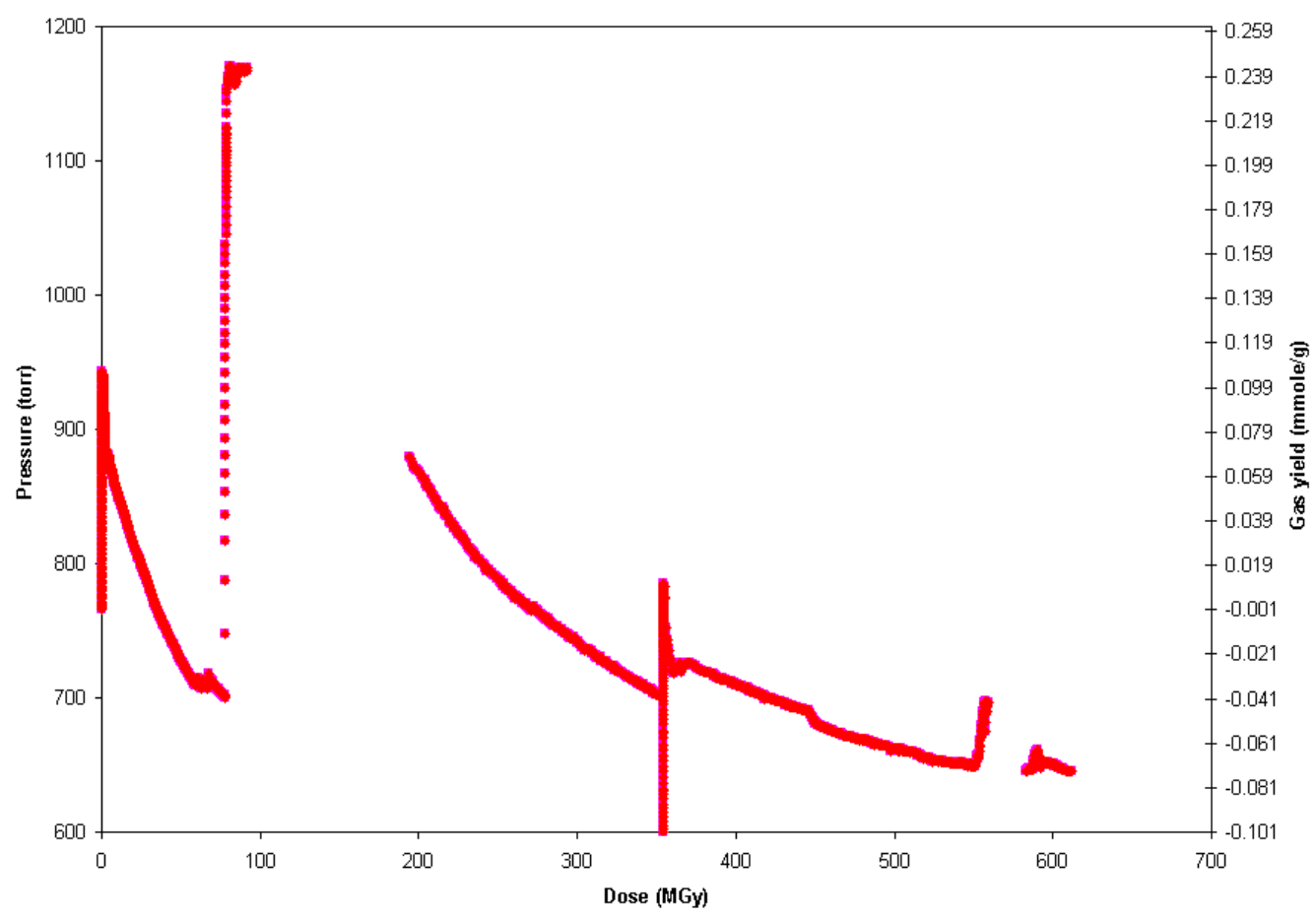

Fig. 4.7. Pressure and gas yield as a function of dose for sample HFIR Np Tube 2 [HFIR SNF-irradiated $\mathrm{NpO}_{2}\left(650^{\circ} \mathrm{C}\right)+1 \mathrm{wt} \% \mathrm{H}_{2} \mathrm{O}$ ].

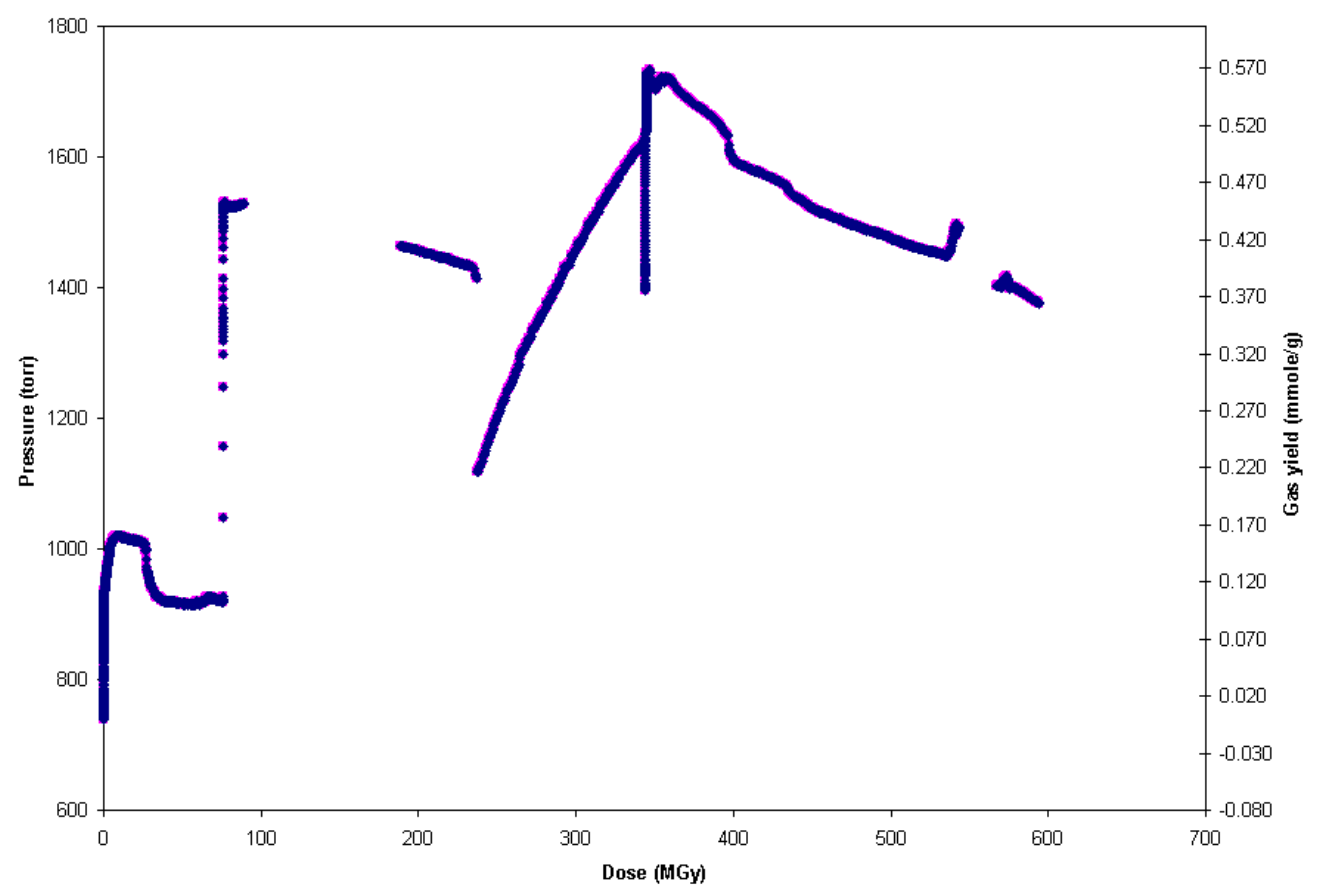

Fig. 4.8. Pressure and gas yield as a function of dose for sample HFIR Np Tube 3 [HFIR SNF-irradiated $\mathrm{NpO}_{2}\left(650^{\circ} \mathrm{C}\right)+8 \mathrm{wt} \% \mathrm{H}_{2} \mathrm{O}$ ] 


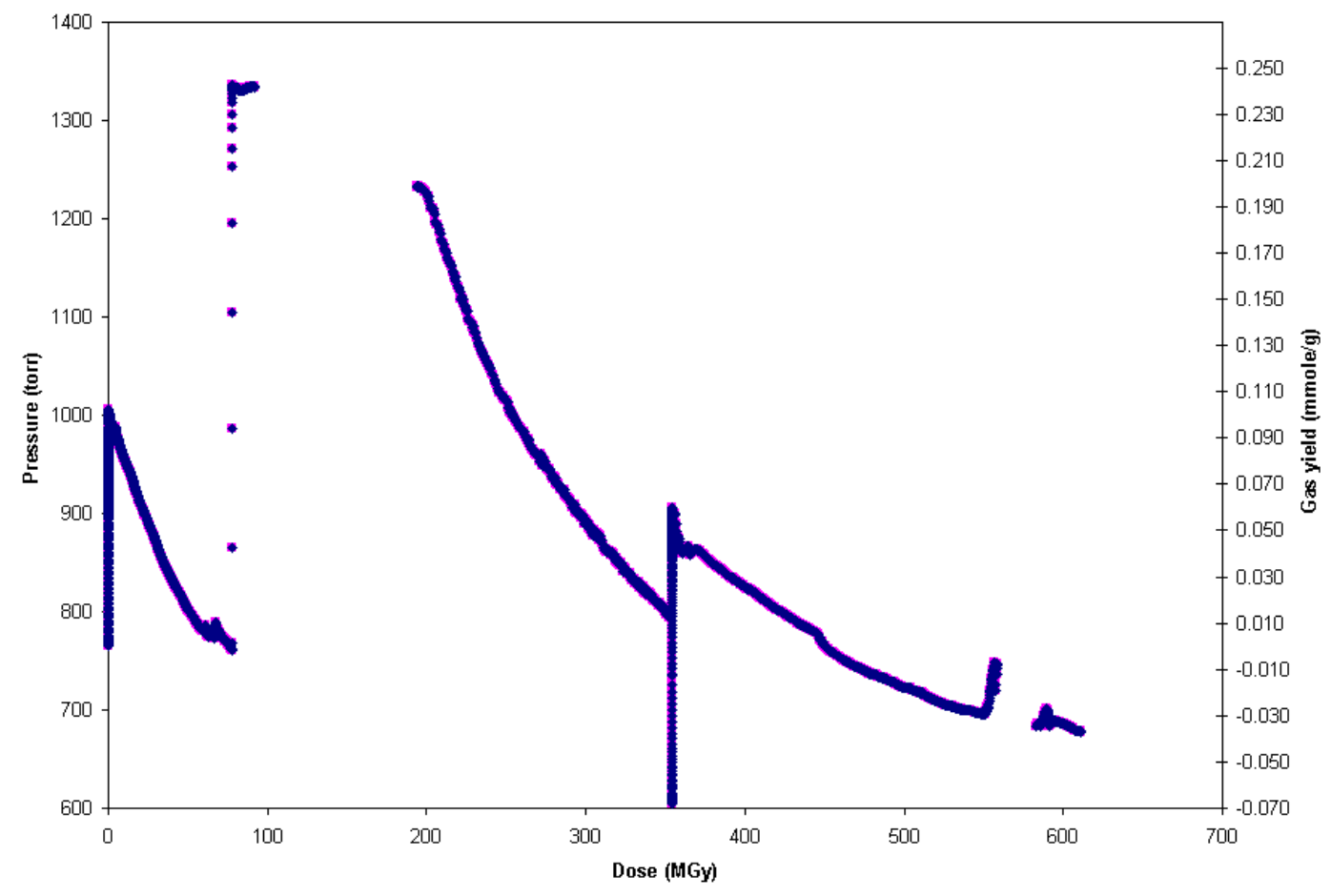

Fig. 4.9. Pressure and gas yield as a function of dose for sample HFIR Np Tube 4 [HFIR SNF-irradiated $\mathrm{NpO}_{2}\left(800^{\circ} \mathrm{C}\right)+1$ wt \% $\mathrm{H}_{2} \mathrm{O}$ ].

The gap in the data for the ${ }^{60} \mathrm{Co}$ irradiations between about 0.5 and $1 \mathrm{MGy}$ for Figs. 4.2-4.5 occurs because the data acquisition system was not working properly during that period. The slope of the gas yield vs dose curve gives (with unit conversion) the G-values that are indicated on the figures for the ${ }^{60} \mathrm{Co}$ experiments.

For the ${ }^{60} \mathrm{Co}$ experiments, the sample that was dry (Fig. 4.2) showed a small pressure increase, followed by a steady pressure decrease. Most of the increase can be attributed to the slight heating of the sample upon insertion into the irradiator. For the sample that contained $8 \mathrm{wt} \%$ moisture (Fig. 4.3), a steady pressure increase was seen. However, the rate of increase appears to slow with higher doses - as evidenced by the two G-values on the plot. This change in slope (G-value) is typical of an approach to a steady-state kinetic condition. The two ${ }^{60} \mathrm{Co}$-irradiated samples that contained $1 \mathrm{wt} \%$ moisture showed a slightly different behavior. The sample prepared at $650^{\circ} \mathrm{C}$ (Fig. 4.4) showed a small initial pressure increase (from about 773 to 778 torr, see insert), followed by a rather rapid pressure decrease to essentially a steady-state value of about 760 torr. The sample prepared at $800^{\circ} \mathrm{C}$ (Fig. 4.5) had an initial pressure increase, which, similar to that presented in Fig. 4.4, could represent the combined effect of heating the sample (with a concomitant increase in vapor pressure of the moisture on the sample) and radiolysis of the moisture on the sample. Afterwards, the pressure was seen to steadily decrease. 
For each of the HFIR SNF experiments (Figs. 4.6-4.9), a number of pressure transients are seen (i.e., at about 0, 90, and $350 \mathrm{MGy}$ ). These transients correspond to the insertion of the experiment into a fresh SNF element (i.e., one that was more recently discharged from the reactor and therefore of much greater gamma intensity).* The transient seen at about $550 \mathrm{MGy}$ reflects an adjustment in the SNF pool temperature. The gap in the data shown in Figs. 4.6-4.9 between about 100 and 200 MGy occurred because the data acquisition system was not working properly during that period.

Each of the HFIR SNF-irradiated samples generally exhibited a similar behavior. Upon insertion into a fuel element, a pressure increase was observed, followed by a pressure decrease. In fact, if one disregards the transients, the overall trend is a pressure decrease. The increases during the transients are larger for the moisture-loaded samples (Figs. 4.7-4.9) than for the dry sample (Fig. 4.6). Again, the combined effects of heating and radiolysis are occurring during these transients.

In Fig. 4.8, which represents a HFIR sample that is heavily loaded with water, an additional transient is seen between about 220 and $350 \mathrm{MGy}$. The pressure is observed to quickly drop and then rise steadily. Otherwise, the behavior is very similar to that for the other samples. No explanation has been found for this transient, nor did time permit further exploration of this observation.

\subsubsection{Gas Analyses}

Results from the gas samples withdrawn from the containers at the completion of the irradiations are presented in Tables 4.2 and 4.3 for the ${ }^{60} \mathrm{Co}$ and the HFIR SNF experiments, respectively. Pressure and temperature data are also included in the tables. The values labeled as "initial" are those at the beginning of the experiment. The "final" values were taken just prior to withdrawal of the gas sample. As indicated in the tables, both the ${ }^{60} \mathrm{Co}$ and HFIR SNF experiments were loaded in air. However, there was a small amount of residual helium in each of the containers after leak testing.

To provide better insight into the change in the gas composition as a result of irradiation, the changes in the number of moles of $\mathrm{O}_{2}, \mathrm{CO}_{2}$, and $\mathrm{H}_{2}$ were calculated by assuming that the starting sample atmosphere was the standard air composition (less any residual helium in the sample tubes). ${ }^{12}$ The results of these calculations are shown in Table 4.4 . To put the measured $\mathrm{H}_{2}$ yields in perspective, Table 4.5 provides the $\mathrm{H}_{2}$ yields as a mole percentage of the initial amount of water available for radiolysis. Additionally, for the samples that had a net oxygen production, the $\mathrm{O}_{2}$-plus- $\mathrm{CO}_{2}$ yields as a mole percentage of the initial amount of water available for radiolysis are presented in Table 4.5.

The gas analysis for the ${ }^{60} \mathrm{Co}$-irradiated samples containing \#1 wt $\% \mathrm{H}_{2} \mathrm{O}$ showed, in general, $\mathrm{O}_{2}$ consumption and a small amount of $\mathrm{H}_{2}$ production $(<1 \mathrm{vol} \%)$. A small amount of $\mathrm{NO}_{x}$ was also detected

\footnotetext{
* The insertion into a fresher element increases both the sample temperature and the radiolysis of any moisture that is present.
} 
for each of the samples, which is a typical occurrence in the radiolysis of moist air. ${ }^{13-15}$ Because this phenomenon is of no significance in the interpretation of the overall radiolysis experiments, it is not discussed further. The ${ }^{60} \mathrm{Co}$-irradiated sample containing $8 \mathrm{wt} \% \mathrm{H}_{2} \mathrm{O}$ - which was clearly much greater than any amount of moisture possible by physi- or chemisorption - exhibited both $\mathrm{H}_{2}$ and $\mathrm{O}_{2}$ production. In fact, Table 4.4 shows that this production was nearly stoichiometric. For the $1 \mathrm{wt} \%$ moisture-laden samples, the $\mathrm{O}_{2}$ consumption is nearly balanced by $\mathrm{CO}_{2}$ production. For the dry $\mathrm{NpO}_{2}$, the $\mathrm{CO}_{2}$ production is about one-tenth the $\mathrm{O}_{2}$ consumption. For each of the ${ }^{60} \mathrm{Co}$-irradiated samples that contained water, a very small percentage of the available water was found as $\mathrm{H}_{2}$ gas after irradiation (Table 4.5).

Table 4.2. Results of mass spectrometric analysis of gas composition from ${ }^{60} \mathrm{Co}$-irradiated $\mathrm{NpO}_{2}$ samples

\begin{tabular}{|c|c|c|c|c|}
\hline & $\begin{array}{l}{ }^{60} \mathrm{Co} \mathrm{Np} \text { Tube } 1 \\
{\left[\mathrm{NpO}_{2}\left(650^{\circ} \mathrm{C}\right)\right]} \\
\end{array}$ & $\begin{array}{l}{ }^{60} \mathrm{Co} \mathrm{Np} \text { Tube } 2 \\
{\left[\mathrm{NpO}_{2}\left(650^{\circ} \mathrm{C}\right)\right.} \\
\left.+8 \mathrm{wt} \% \mathrm{H}_{2} \mathrm{O}\right] \\
\end{array}$ & $\begin{array}{l}{ }^{60} \mathrm{Co} \mathrm{Np} \text { Tube } 3 \\
{\left[\mathrm{NpO}_{2}\left(650^{\circ} \mathrm{C}\right)\right.} \\
\left.+1 \mathrm{wt} \% \mathrm{H}_{2} \mathrm{O}\right] \\
\end{array}$ & $\begin{array}{l}{ }^{60} \mathrm{Co} \mathrm{Np} \mathrm{Tube} 4 \\
{\left[\mathrm{NpO}_{2}\left(8_{00}{ }^{\circ} \mathrm{C}\right)\right.} \\
\left.+1 \mathrm{wt} \% \mathrm{H}_{2} \mathrm{O}\right] \\
\end{array}$ \\
\hline Initial atmosphere & Air & Air & Air & Air \\
\hline Initial pressure $^{a}$ (torr) & 741 & 749 & 773 & 738 \\
\hline Initial temperature ${ }^{a}\left({ }^{\circ} \mathrm{C}\right)$ & 22 & 22 & 22 & 22 \\
\hline Final pressure ${ }^{b}$ (torr) & 709 & 952 & 764 & 746 \\
\hline \multirow[t]{2}{*}{ Final temperature ${ }^{b}\left({ }^{o} \mathrm{C}\right)$} & 25 & 25 & 25 & 25 \\
\hline & \multicolumn{4}{|c|}{ Gas composition (vol \%) } \\
\hline $\mathrm{CO}_{2}$ & 0.89 & 1.1 & 2.05 & 4.9 \\
\hline $\mathrm{Ar}$ & 1.04 & 0.8 & 0.98 & 1.01 \\
\hline $\mathrm{O}_{2}$ & 15.07 & 21.08 & 18.22 & 13.38 \\
\hline $\mathrm{N}_{2}$ & 80.13 & 62.4 & 74.52 & 77.32 \\
\hline $\mathrm{H}_{2}$ & 0.01 & 12.01 & 0.94 & 0.24 \\
\hline $\mathrm{He}$ & 2.25 & 2.07 & 2.9 & 1.7 \\
\hline $\mathrm{H}_{2} \mathrm{O}$ & 0.48 & 0.35 & 0.1 & 0.09 \\
\hline $\mathrm{NO}_{x}$ & 0.1 & 0.03 & 0.13 & 1.22 \\
\hline
\end{tabular}

${ }^{a}$ Value at beginning of the experiment.

${ }^{b}$ Value just prior to withdrawal of gas sample. 
Table 4.3. Results of mass spectrometric analysis of gas composition from HFIR SNF-irradiated $\mathrm{NpO}_{2}$ samples

\begin{tabular}{|c|c|c|c|c|}
\hline & $\begin{array}{l}\text { HFIR Np Tube } 1 \\
{\left[\mathrm{NpO}_{2}\left(650^{\circ} \mathrm{C}\right)\right]}\end{array}$ & $\begin{array}{l}\text { HFIR Np Tube } 2 \\
{\left[\mathrm{NpO}_{2}\left(650^{\circ} \mathrm{C}\right)\right.} \\
\left.+1 \mathrm{wt} \% \mathrm{H}_{2} \mathrm{O}\right] \\
\end{array}$ & $\begin{array}{c}\text { HFIR Np Tube } 3 \\
{\left[\mathrm{NpO}_{2}\left(650^{\circ} \mathrm{C}\right)\right.} \\
\left.+8 \mathrm{wt} \% \mathrm{H}_{2} \mathrm{O}\right]\end{array}$ & $\begin{array}{l}\text { HFIR Np Tube } 4 \\
{\left[\mathrm{NpO}_{2}\left(8_{00}^{\circ} \mathrm{C}\right)\right.} \\
\left.+1 \mathrm{wt} \% \mathrm{H}_{2} \mathrm{O}\right] \\
\end{array}$ \\
\hline Initial atmosphere & Air & Air & Air & Air \\
\hline Initial pressure $^{a}$ (torr) & 759 & 766 & 739 & 766 \\
\hline Initial temperature ${ }^{a, b}\left({ }^{\circ} \mathrm{C}\right)$ & 40 & 40 & 40 & 40 \\
\hline Final pressure $^{c}$ (torr) & 629 & 645 & 1376 & 678 \\
\hline \multirow[t]{2}{*}{ Final temperature ${ }^{c, d}\left({ }^{\circ} \mathrm{C}\right)$} & 55 & 55 & 55 & 55 \\
\hline & \multicolumn{4}{|c|}{ Gas composition (vol \%) } \\
\hline $\mathrm{CO}_{2}$ & 2.32 & 0.04 & 0.005 & 1.68 \\
\hline $\mathrm{Ar}$ & 1.23 & 1.27 & 0.59 & 1.22 \\
\hline $\mathrm{O}_{2}$ & 3.21 & 0.06 & 16.84 & 0.04 \\
\hline $\mathrm{N}_{2}$ & 90.09 & 96.13 & 45.96 & 96.6 \\
\hline $\mathrm{H}_{2}$ & 0.05 & 0.006 & 35.46 & 0.026 \\
\hline $\mathrm{He}$ & 2.05 & 1.9 & 0.9 & 0.13 \\
\hline $\mathrm{CO}$ & 0.1 & $<0.01$ & $<0.01$ & $<0.01$ \\
\hline $\mathrm{NO}_{x}$ & 0.9 & 0.54 & 0.16 & 0.15 \\
\hline
\end{tabular}

${ }^{a}$ Value at beginning of the experiment.

${ }^{b}$ Typical SNF pool temperature.

${ }^{c}$ Value just prior to withdrawal of gas sample.

${ }^{d}$ Average temperature of container inside element (based on previous experiments). 
Table 4.4. Estimated change in gas composition for selected experiments as a result of radiolysis

\begin{tabular}{|c|c|c|c|c|}
\hline Experiment & Material $^{a}$ & $\Delta \mathrm{O}_{2}(\mathrm{~mol})$ & $\Delta \mathrm{CO}_{2}(\mathrm{~mol})$ & $\Delta \mathrm{H}_{2}(\mathrm{~mol})$ \\
\hline${ }^{60} \mathrm{Co} \mathrm{Np}$ Tube 1 & $\mathrm{NpO}_{2}\left(650^{\circ} \mathrm{C}\right)$ & $! 4.1 \times 10^{! 5}$ & $5.3 \times 10^{! 6}$ & $6.2 \times 10^{! 8}$ \\
\hline${ }^{60} \mathrm{Co} \mathrm{Np}$ Tube 2 & $\begin{array}{l}\mathrm{NpO}_{2}\left(650^{\circ} \mathrm{C}\right) \\
+8 \text { wt } \% \mathrm{H}_{2} \mathrm{O}\end{array}$ & $3.9 \times 10^{! 5}$ & $8.7 \times 10^{! 6}$ & $9.8 \times 10^{! 5}$ \\
\hline${ }^{60} \mathrm{Co} \mathrm{Np}$ Tube 3 & $\begin{array}{l}\mathrm{NpO}_{2}\left(650^{\circ} \mathrm{C}\right) \\
+1 \mathrm{wt} \% \mathrm{H}_{2} \mathrm{O}\end{array}$ & $! 1.7 \times 10^{! 5}$ & $1.3 \times 10^{! 5}$ & $6.2 \times 10^{! 6}$ \\
\hline${ }^{60} \mathrm{Co} \mathrm{Np}$ Tube 4 & $\begin{array}{l}\mathrm{NpO}_{2}\left(800^{\circ} \mathrm{C}\right) \\
+1 \text { wt } \% \mathrm{H}_{2} \mathrm{O}\end{array}$ & $! 4.5 \times 10^{! 5}$ & $3.7 \times 10^{! 5}$ & $1.5 \times 10^{! 6}$ \\
\hline HFIR Np Tube 1 & $\mathrm{NpO}_{2}\left(650^{\circ} \mathrm{C}\right)$ & $! 2.4 \times 10^{! 4}$ & $2.4 \times 10^{! 5}$ & $5.3 \times 10^{! 7}$ \\
\hline HFIR Np Tube 2 & $\begin{array}{l}\mathrm{NpO}_{2}\left(650^{\circ} \mathrm{C}\right) \\
+1 \mathrm{wt} \% \mathrm{H}_{2} \mathrm{O}\end{array}$ & $! 4.0 \times 10^{! 4}$ & $2.4 \times 10^{! 8}$ & $9.3 \times 10^{! 8}$ \\
\hline HFIR Np Tube 3 & $\begin{array}{l}\mathrm{NpO}_{2}\left(650^{\circ} \mathrm{C}\right) \\
+8 \mathrm{wt} \% \mathrm{H}_{2} \mathrm{O}\end{array}$ & $1.8 \times 10^{! 4}$ & $! 4.2 \times 10^{! 7}$ & $1.2 \times 10^{! 3}$ \\
\hline HFIR Np Tube 4 & $\begin{array}{l}\mathrm{NpO}_{2}\left(800^{\circ}\right) \\
+1 \text { wt } \% \mathrm{H}_{2} \mathrm{O}\end{array}$ & $! 2.9 \times 10^{! 4}$ & $1.9 \times 10^{! 5}$ & $3.0 \times 10^{! 7}$ \\
\hline Alpha Np Tube 1 & $\mathrm{NpO}_{2}\left(650^{\circ} \mathrm{C}\right)$ & $! 5.4 \times 10^{! 5}$ & $6.5 \times 10^{! 6}$ & $8.7 \times 10^{! 7}$ \\
\hline Alpha Np Tube 2 & $\begin{array}{l}\mathrm{NpO}_{2}\left(650^{\circ} \mathrm{C}\right) \\
+1 \mathrm{wt} \% \mathrm{H}_{2} \mathrm{O}\end{array}$ & $5.2 \times 10^{! 5}$ & $! 9.6 \times 10^{!} 8$ & $1.1 \times 10^{! 4}$ \\
\hline $\begin{array}{l}\text { Alpha Np Tube } 3 \\
\text { (first gas sample) }\end{array}$ & $\begin{array}{l}\mathrm{NpO}_{2}\left(650^{\circ} \mathrm{C}\right) \\
+8 \text { wt } \% \mathrm{H}_{2} \mathrm{O}\end{array}$ & $8.7 \times 10^{! 4}$ & $1.2 \times 10^{! 6}$ & $1.7 \times 10^{! 3}$ \\
\hline Alpha Np Tube 4 & $\begin{array}{l}\mathrm{NpO}_{2}\left(800^{\circ} \mathrm{C}\right) \\
+1 \text { wt } \% \mathrm{H}_{2} \mathrm{O}\end{array}$ & $7.5 \times 10^{! 6}$ & $4.1 \times 10^{! 7}$ & $8.1 \times 10^{! 5}$ \\
\hline Alpha Np Tube 5 & $\begin{array}{l}\mathrm{NpO}_{2}\left(650^{\circ} \mathrm{C}\right) \\
+0.5 \mathrm{wt} \% \mathrm{H}_{2} \mathrm{O}\end{array}$ & $b$ & $b$ & $6.9 \times 10^{! 6}$ \\
\hline
\end{tabular}

\footnotetext{
${ }^{a}$ Value in parenthesis denotes preparation temperature.

${ }^{b}$ Excess $\mathrm{O}_{2}$ was initially present in transducer region of sample; therefore, change in $\mathrm{O}_{2}$ and $\mathrm{CO}_{2}$ cannot be estimated.
} 
Table 4.5. Estimated $\mathrm{H}_{2}$ production as a percentage of initial amount of water available for radiolysis

\begin{tabular}{|c|c|c|c|}
\hline Experiment & Material $^{a}$ & $\begin{array}{c}\text { Ratio of } \mathrm{H}_{2} \text { production } \\
\text { to water available } \\
\text { for radiolysis } \\
(\mathrm{mol} \%)\end{array}$ & $\begin{array}{c}\text { Ratio of } \mathrm{O}_{2}+\mathrm{CO}_{2} \\
\text { production to water } \\
\text { available for radiolysis } \\
(\mathrm{mol} \%)\end{array}$ \\
\hline${ }^{60} \mathrm{Co} \mathrm{Np}$ Tube 2 & $\begin{array}{l}\mathrm{NpO}_{2}\left(650^{\circ} \mathrm{C}\right) \\
+8 \mathrm{wt} \% \mathrm{H}_{2} \mathrm{O}\end{array}$ & 0.55 & 0.27 \\
\hline${ }^{60} \mathrm{Co} \mathrm{Np}$ Tube 3 & $\begin{array}{l}\mathrm{NpO}_{2}\left(650^{\circ} \mathrm{C}\right) \\
+1 \text { wt } \% \mathrm{H}_{2} \mathrm{O}\end{array}$ & 0.28 & $b$ \\
\hline${ }^{60} \mathrm{Co} \mathrm{Np}$ Tube 4 & $\begin{array}{l}\mathrm{NpO}_{2}\left(800^{\circ} \mathrm{C}\right) \\
+1 \mathrm{wt} \% \mathrm{H}_{2} \mathrm{O}\end{array}$ & 0.068 & $b$ \\
\hline HFIR Np Tube 2 & $\begin{array}{l}\mathrm{NpO}_{2}\left(650^{\circ} \mathrm{C}\right) \\
+1 \mathrm{wt} \% \mathrm{H}_{2} \mathrm{O}\end{array}$ & 0.0042 & $b$ \\
\hline HFIR Np Tube 3 & $\begin{array}{l}\mathrm{NpO}_{2}\left(650^{\circ} \mathrm{C}\right) \\
+8 \text { wt } \% \mathrm{H}_{2} \mathrm{O}\end{array}$ & 6.7 & 0.99 \\
\hline HFIR Np Tube 4 & $\begin{array}{l}\mathrm{NpO}_{2}\left(800^{\circ} \mathrm{C}\right) \\
+1 \mathrm{wt} \% \mathrm{H}_{2} \mathrm{O}\end{array}$ & 0.014 & $b$ \\
\hline Alpha Np Tube 2 & $\begin{array}{l}\mathrm{NpO}_{2}\left(650^{\circ} \mathrm{C}\right) \\
+1 \mathrm{wt} \% \mathrm{H}_{2} \mathrm{O}\end{array}$ & 6.8 & 3.2 \\
\hline $\begin{array}{l}\text { Alpha Np Tube } 3 \\
\text { (after first gas } \\
\text { sample) }\end{array}$ & $\begin{array}{l}\mathrm{NpO}_{2}\left(650^{\circ} \mathrm{C}\right) \\
+8 \mathrm{wt} \% \mathrm{H}_{2} \mathrm{O}\end{array}$ & 13 & 6.6 \\
\hline Alpha Np Tube 4 & $\begin{array}{l}\mathrm{NpO}_{2}\left(800^{\circ} \mathrm{C}\right) \\
+1 \mathrm{wt} \% \mathrm{H}_{2} \mathrm{O}\end{array}$ & 4.7 & 0.46 \\
\hline Alpha Np Tube 5 & $\begin{array}{c}\mathrm{NpO}_{2}\left(650^{\circ} \mathrm{C}\right) \\
+0.5 \mathrm{wt} \% \mathrm{H}_{2} \mathrm{O}\end{array}$ & 0.8 & $c$ \\
\hline
\end{tabular}


The $\mathrm{NpO}_{2}$ samples containing \#1 wt \% $\mathrm{H}_{2} \mathrm{O}$ that were irradiated in HFIR SNF elements (Figs. 4.6, 4.7, and 4.9) exhibited an overall pressure decrease. The gas analyses for these samples showed that the $\mathrm{O}_{2}$ was almost completely consumed while only a trace of $\mathrm{H}_{2}$ was produced. The $\mathrm{CO}_{2}$ production was \#10\% of the $\mathrm{O}_{2}$ consumption for HFIR Np Tube 1 and HFIR Np Tube 4. Only a trace of $\mathrm{CO}_{2}$ was produced for HFIR Np Tube 2. By contrast, the sample containing 8\% water (Fig. 4.8) had a net pressure increase. In this experiment, the pressure appeared to peak and then slowly decrease. The gas analysis for the $8 \%$ sample showed that a rather large amount of $\mathrm{H}_{2}(\sim 35 \mathrm{vol} \%$, Table 4.3$)$ was produced. It also appears from this table alone that a stoichiometric amount of $\mathrm{O}_{2}$ was produced; however, closer examination of the net change in each component (Table 4.4) shows that the net $\mathrm{O}_{2}$ production was $15 \%$ of the hydrogen production. Only in the case of HFIR Np Tube 3 was the $\mathrm{H}_{2}$ production a significant fraction of the available $\mathrm{H}_{2} \mathrm{O}$ (Table 4.5).

\subsection{ALPHA RADIOLYSIS EXPERIMENTS}

Table 4.6 provides a summary of the alpha irradiation experiments that were performed. Irradiation times ranged from 110 to 295 days. Considering the higher dose rate of the ${ }^{244} \mathrm{Cm}$ as compared with the

${ }^{238} \mathrm{Pu}$ (see Fig. 3.8), this would correspond to equivalent irradiation times ranging from 21 to 57 years for the SRS neptunium.

Table 4.6. Summary of alpha irradiation experiments performed

\begin{tabular}{|c|c|c|c|c|}
\hline Experiment & Material $^{a}$ & Mass (g) & ${ }^{244} \mathrm{Cm}$ added (mg) & $\begin{array}{l}\text { Total dose } \\
\left(\mathrm{MGy}^{b}\right.\end{array}$ \\
\hline Alpha Np Tube 1 & $\mathrm{NpO}_{2}\left(650^{\circ} \mathrm{C}\right)$ & 2.95 & 18.72 & 280 \\
\hline Alpha Np Tube 2 & $\begin{array}{l}\mathrm{NpO}_{2}\left(650^{\circ} \mathrm{C}\right) \\
+1 \mathrm{wt} \% \mathrm{H}_{2} \mathrm{O}\end{array}$ & 2.96996 & 18.66 & 439 \\
\hline Alpha Np Tube 3 & $\begin{array}{l}\mathrm{NpO}_{2}\left(650^{\circ} \mathrm{C}\right) \\
+8 \mathrm{wt} \% \mathrm{H}_{2} \mathrm{O}\end{array}$ & 3.175 & 18.66 & 410 \\
\hline Alpha Np Tube 4 & $\begin{array}{l}\mathrm{NpO}_{2}\left(800^{\circ} \mathrm{C}\right) \\
+1 \mathrm{wt} \% \mathrm{H}_{2} \mathrm{O}\end{array}$ & 3.130 & 19.68 & 439 \\
\hline Alpha Np Tube 5 & $\begin{array}{l}\mathrm{NpO}_{2}\left(650^{\circ} \mathrm{C}\right) \\
+0.5 \mathrm{wt} \% \mathrm{H}_{2} \mathrm{O}\end{array}$ & 2.96475 & 18.72 & 166 \\
\hline
\end{tabular}

${ }^{a}$ Value in parenthesis denotes preparation temperature.

${ }^{b}$ Dose calculated by depositing all of the alpha decay energy in the sample (i.e., $\mathrm{NpO}_{2}+\mathrm{H}_{2} \mathrm{O}$ ). 


\subsubsection{Pressure Measurements}

Pressure within the sample containers was monitored throughout the irradiations, and the pressure data from each of the experiments are shown in Figs. 4.10-4.14. G-values, which were calculated from the slope of the curves, are also presented in these figures.

The dry $\mathrm{NpO}_{2}$ sample (Fig. 4.10) exhibited a steady pressure decrease. As seen in Fig. 4.10, a gas sample was withdrawn from Alpha Np Tube 1 after a dose of about $140 \mathrm{MGy}$. The tube was then backfilled with $\mathrm{O}_{2}$ to a total pressure of about 1350 torr. The pressure again decreased, although at what appears to be at a higher rate than previously seen. Additionally, with increasing dose, the pressure appears to approach a steady state. After about 280-MGy total dose, this tube (which contained dry $\mathrm{NpO}_{2}$ ) was opened and $0.5 \mathrm{wt} \%$ moisture was added. This sample then became experiment Alpha Np Tube 5 (Fig. 4.14).

Both of the samples that contained $1 \mathrm{wt} \%$ moisture (Figs. 4.11 and 4.13) exhibited similar behavior. The pressure steadily increased and approached what appeared to be a plateau. A gas sample was withdrawn from Alpha Np Tube 2 (Fig. 4.11) after a dose of about 140 MGy. The tube was then vented to the glove box and isolated. The experiment continued, whereupon the pressure increased slightly, followed by an overall decrease. Hence, the plateau that was seen just before gas sampling was probably a peak - one that would have been followed by a pressure decrease had a gas sample not been withdrawn.

Similar to Alpha Np Tube 2, a gas sample was withdrawn from Alpha Np Tube 4 after a dose of about 140 MGy (Fig. 4.13). This tube was then vented to the glove box and resealed, and the experiment continued. Again, the pressure increased slightly, followed by a decrease.

For Alpha Np Tube 3 (Fig. 4.12), gas samples were withdrawn after about 80- and 130-MGy total dose. The tube was vented to the glove box (no gas sample taken) after a dose of almost $250 \mathrm{MGy}$. It was then resealed, and the experiment was continued. However, a final gas sample was not withdrawn. Throughout the irradiation of Alpha Np Tube 3, a steady pressure increase was noted. After each sample withdrawal or pressure reduction, the rate of pressure increase slowed, as shown by comparing the G-values for each segment. These decreasing G-values again indicate the approach to a steady state.

The sample that contained the $0.5 \mathrm{wt} \%$ moisture (Fig. 4.14) showed a steady pressure increase to a plateau. This sample had originally been the dry $\mathrm{NpO}_{2}$ (Alpha Np Tube 1), which had been exposed to excess oxygen. As seen in Fig. 4.14, a gas sample was withdrawn from Alpha Np Tube 5 after a total dose of about 130 MGy. 


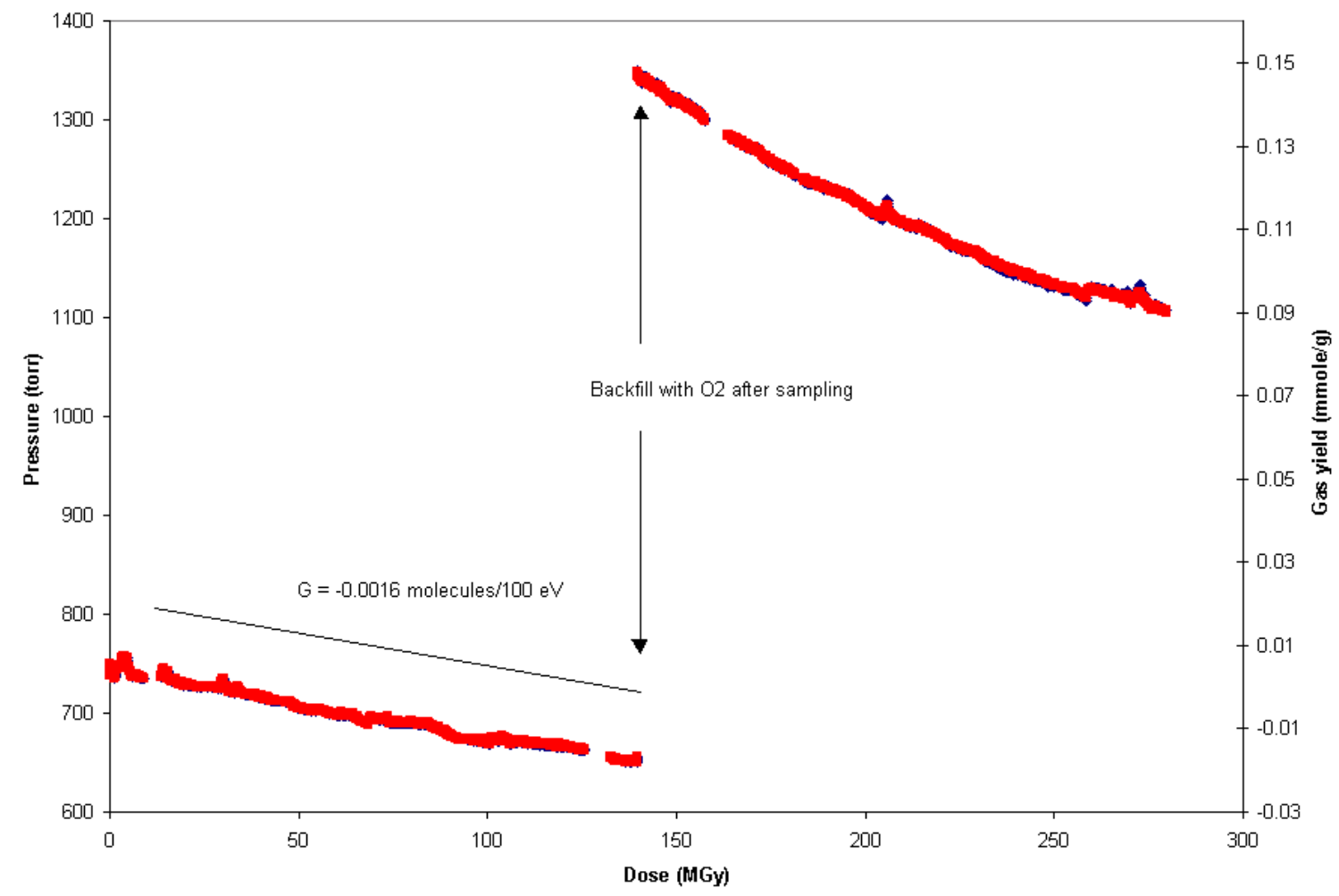

Fig. 4.10. Pressure and gas yield as a function of dose for sample Alpha $N p$ Tube $1\left[{ }^{244} \mathrm{Cm}\right.$ alpha-irradiated $\left.\mathrm{NpO}_{2}\left(650^{\circ} \mathrm{C}\right)\right]$.

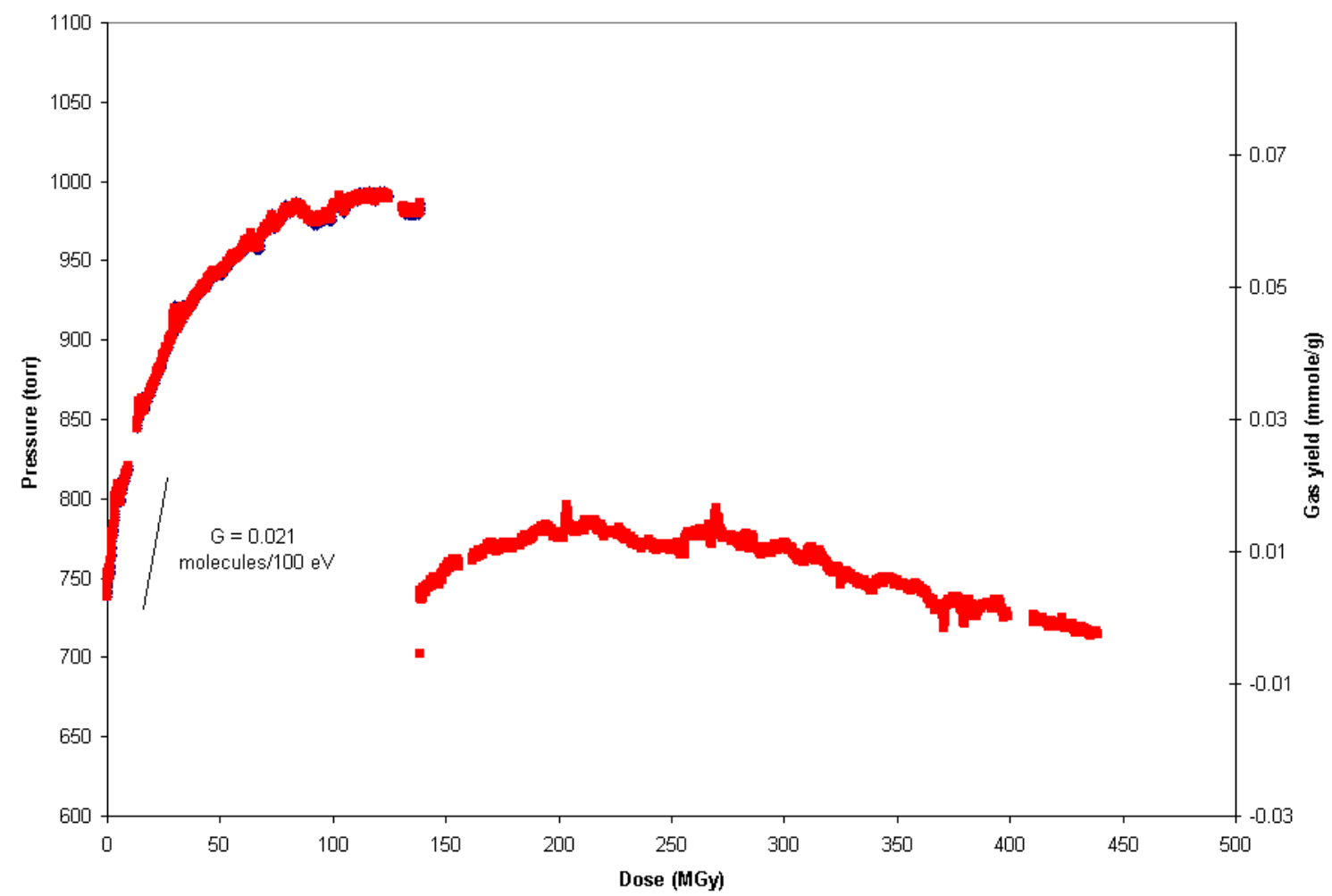

Fig. 4.11. Pressure and gas yield as a function of dose for sample Alpha Np Tube $2\left[{ }^{244} \mathrm{Cm}\right.$ alpha-irradiated $\mathrm{NpO}_{2}\left(650^{\circ}\right)+1$ wt \% $\left.\mathrm{H}_{2} \mathrm{O}\right]$. 


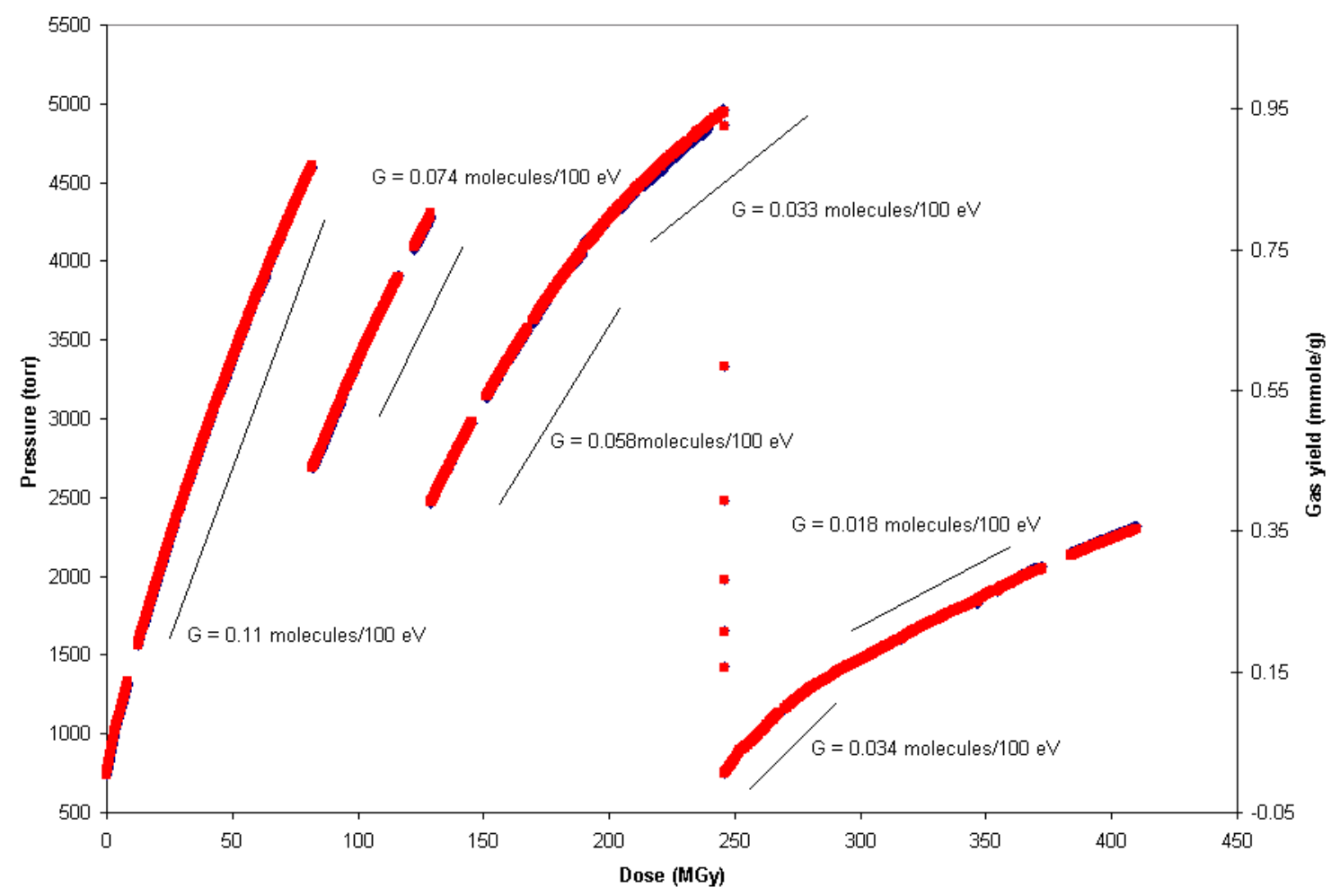

Fig. 4.12. Pressure and gas yield as a function of dose for sample Alpha Np Tube $3\left[{ }^{244} \mathrm{Cm}\right.$ alpha-irradiated $\left.\mathrm{NpO}_{2}\left(650^{\circ} \mathrm{C}\right)+8 \mathrm{wt} \% \mathrm{H}_{2} \mathrm{O}\right]$.

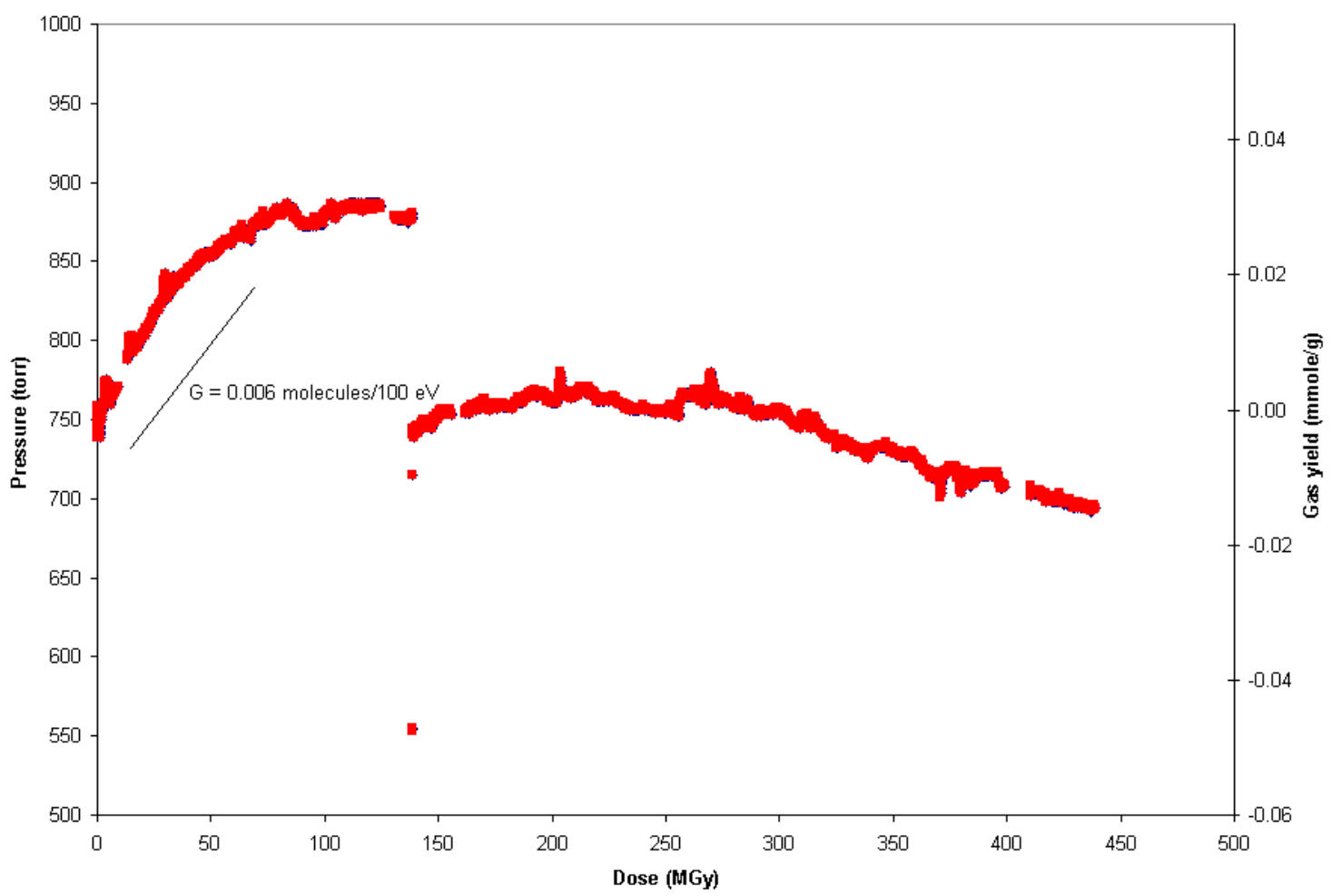

Fig. 4.13. Pressure and gas yield as a function of dose for sample Alpha Np Tube $4\left[{ }^{244} \mathrm{Cm}\right.$ alpha-irradiated $\left.\mathrm{NpO}_{2}\left(800^{\circ} \mathrm{C}\right)+1 \mathrm{wt} \% \mathrm{H}_{2} \mathrm{O}\right]$. 


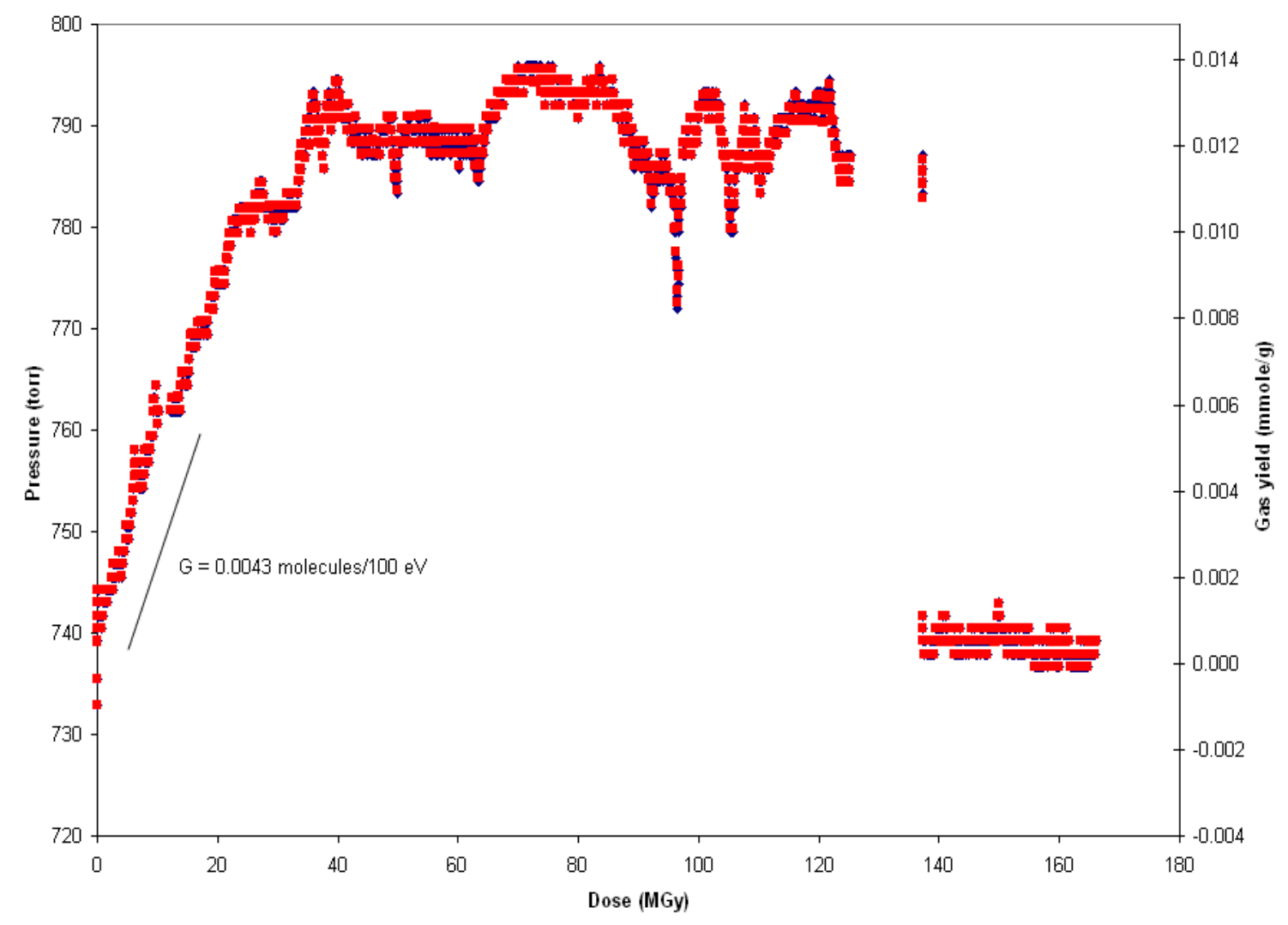

Fig. 4.14. Pressure and gas yield as a function of dose for sample Alpha Np Tube $5\left[^{244} \mathrm{Cm}\right.$ alphairradiated $\left.\mathrm{NpO}_{2}\left(650^{\circ} \mathrm{C}\right)+0.5 \mathrm{wt} \% \mathrm{H}_{2} \mathrm{O}\right]$.

\subsubsection{Gas Analyses}

Gas samples were periodically withdrawn from the containers during the experiments. Analytical results for these samples are presented in Table 4.7, which also includes pressure and temperature data. As in the gamma irradiation experiments, the values labeled as "initial" are those at the beginning of the experiment or, in the case of multiple gas samples, the value just after sampling. The "final" values are taken just prior to withdrawal of the gas sample.

The calculated changes in the moles of $\mathrm{O}_{2}, \mathrm{CO}_{2}$, and $\mathrm{H}_{2}$ (assuming that the starting sample atmosphere was the standard air composition, ${ }^{12}$ less any residual helium in the sample tubes) are shown in Table 4.4. (No such calculation was made for Alpha Np Tube 5. While air was present immediately over this sample, the sample initially had additional $\mathrm{O}_{2}$ and helium that were present in the pressure-transducer region.) Table 4.5 provides (1) $\mathrm{H}_{2}$ yields and (2) $\mathrm{O}_{2}$-plus- $\mathrm{CO}_{2}$ yields (for the samples that had a net oxygen production) as a mole percentage of the initial amount of water available for radiolysis. 
Table 4.7. Results of mass spectrometric analysis of gas composition from alpha-irradiated $\mathrm{NpO}_{2}$ samples

\begin{tabular}{|c|c|c|c|c|c|c|}
\hline & \multirow{2}{*}{$\begin{array}{l}\text { Alpha Np Tube } 1 \\
\mathrm{NpO}_{2}\left(650^{\circ} \mathrm{C}\right)\end{array}$} & \multirow{2}{*}{$\begin{array}{l}\text { Alpha Np Tube } 2 \\
\mathrm{NpO}_{2}\left(650^{\circ} \mathrm{C}\right) \\
+1 \mathrm{wt} \% \mathrm{H}_{2} \mathrm{O}\end{array}$} & \multicolumn{2}{|c|}{$\begin{array}{c}\text { Alpha Np Tube } 3 \\
\mathrm{NpO}_{2}\left(650^{\circ} \mathrm{C}\right)+8 \mathrm{wt} \% \mathrm{H}_{2} \mathrm{O}\end{array}$} & \multirow{2}{*}{$\begin{array}{c}\text { Alpha Np Tube } 4 \\
\mathrm{NpO}_{2}\left(800^{\circ} \mathrm{C}\right) \\
+1 \mathrm{wt} \% \mathrm{H}_{2} \mathrm{O}\end{array}$} & \multirow{2}{*}{$\begin{array}{l}\text { Alpha Np Tube } 5 \\
\mathrm{NpO}_{2}\left(650^{\circ} \mathrm{C}\right) \\
+0.5 \text { wt } \% \mathrm{H}_{2} \mathrm{O}\end{array}$} \\
\hline & & & First gas sample & Second gas sample & & \\
\hline Initial atmosphere & Air & Air & Air & $\begin{array}{l}\text { First gas sample } \\
\text { composition (no } \\
\text { helium) }\end{array}$ & Air & Air/excess $\mathrm{O}_{2}{ }^{a}$ \\
\hline Initial pressure $^{b}$ (torr) & 739 & 738 & 740 & 2683 & 740 & 735 \\
\hline Initial temperature ${ }^{b}\left({ }^{\circ} \mathrm{C}\right)$ & 19.5 & 17.2 & 18.3 & 18.9 & 19.5 & 19.8 \\
\hline Final pressure $^{c}$ (torr) & 656 & 986 & 4601 & 4292 & 881 & 786 \\
\hline \multirow[t]{2}{*}{ Final temperature ${ }^{c}\left({ }^{\circ} \mathrm{C}\right)$} & 19.6 & 19.6 & 18.9 & 18.5 & 19.1 & 23.0 \\
\hline & \multicolumn{6}{|c|}{ Gas composition (vol \%) } \\
\hline $\mathrm{CO}_{2}$ & 0.9 & 0.1 & 0.04 & 0.025 & 0.07 & 0.02 \\
\hline $\mathrm{Ar}$ & 0.65 & 0.54 & 0.2 & 0.1 & 0.61 & 0.47 \\
\hline $\mathrm{O}_{2}$ & 7.4 & 17.27 & 28.9 & 30.16 & 14.26 & 42.63 \\
\hline $\mathrm{N}_{2}$ & 52.0 & 44.4 & 17.52 & 7.95 & 50.79 & 54.11 \\
\hline $\mathrm{H}_{2}$ & 0.12 & 11.72 & 50.26 & 58.57 & 9.54 & 1.27 \\
\hline $\mathrm{He}^{d}$ & 38.03 & 25.55 & 2.85 & 2.97 & 23.92 & 1.09 \\
\hline $\mathrm{H}_{2} \mathrm{O}$ & 0.2 & 0.1 & & 0.2 & 0.2 & \\
\hline $\mathrm{NO}_{\mathrm{x}}$ & 0.6 & 0.39 & 0.05 & 0.02 & 0.6 & 0.4 \\
\hline $\mathrm{CH}_{4}$ & 0.004 & 0.003 & $<0.01$ & $<0.01$ & 0.005 & $<0.01$ \\
\hline $\mathrm{CO}$ & $<0.01$ & $<0.01$ & $<0.01$ & $<0.01$ & $<0.01$ & 0.006 \\
\hline
\end{tabular}

${ }^{a}$ Tube 5 was made by taking the Tube 1 experiment and adding $0.5 \mathrm{wt} \%$ water. Prior to this addition, Tube 1 had been backfilled with $\mathrm{O}_{2}$. Because the pressure transducer and sampling line were not flushed with air prior to the water addition, the initial atmosphere in the pressure-transducer region likely had an excess of $\mathrm{O}_{2}$. The atmosphere directly over the sample was air.

${ }^{b}$ Value at beginning of experiment or just after previous gas-sampling operation.

${ }^{c}$ Value just prior to withdrawal of gas sample.

${ }^{d}$ Helium was an artifact of the sampling method. 
The dry $\mathrm{NpO}_{2}$ sample that was irradiated with the alpha from ${ }^{244} \mathrm{Cm}$ (Fig. 4.10) showed a pressure decrease to vacuum (i.e., a pressure less than atmospheric). The gas sample from this experiment confirmed that $\mathrm{O}_{2}$ was consumed. After the gas sample was withdrawn, this container was backfilled with $\mathrm{O}_{2}$ and the sample pressure continued to decrease, likely from further $\mathrm{O}_{2}$ consumption. (A final gas sample was not withdrawn.)

Both of the alpha-irradiated $\mathrm{NpO}_{2}$ samples that had $1 \mathrm{wt} \%$ sorbed moisture exhibited a pressure increase to an apparent steady-state plateau at 100-130 MGy (Figs. 4.11 and 4.13). The sample prepared at $650^{\circ} \mathrm{C}$ increased about 250 torr, while that prepared at $800^{\circ} \mathrm{C}$ increased about 140 torr. The steady-state plateau represents a situation in which back reactions (i.e., $\mathrm{H}_{2}$ and $\mathrm{O}_{2}$ recombination) balance forward reactions (i.e., $\mathrm{H}_{2}$ and $\mathrm{O}_{2}$ production). The gas analysis results for these two experiments revealed that both $\mathrm{H}_{2}$ and $\mathrm{O}_{2}$ were produced. For Alpha Np Tube 2, a stoichiometric mixture of $\mathrm{H}_{2}$ and $\mathrm{O}_{2}$ was present at the plateau. However, for Alpha $\mathrm{Np}$ Tube 4, the $\mathrm{O}_{2}$ production was only about $10 \%$ of the $\mathrm{H}_{2}$ production (Table 4.4). A small amount of $\mathrm{NO}_{x}$ was also detected. After sampling, both tubes were vented with the glove-box atmosphere and then closed. Both experiments showed a small pressure increase followed by a decrease, probably indicating the consumption of some excess $\mathrm{O}_{2}$ in the system, as was seen before in other experiments. However, a final gas sample was not taken.

The alpha-irradiated $\mathrm{NpO}_{2}$ sample that contained $8 \mathrm{wt} \% \mathrm{H}_{2} \mathrm{O}$ exhibited a steady increase in pressure (Fig. 4.12). The initial gas analysis of a sample taken after 80-MGy total dose showed that both $\mathrm{H}_{2}$ and $\mathrm{O}_{2}$ were produced in stoichiometric proportions. A second gas sample after about $130 \mathrm{MGy}$ showed further $\mathrm{H}_{2}$ and $\mathrm{O}_{2}$ production. As indicated in Fig. 4.12, the pressure increased at a decreasing rate; however, for this experiment, a pressure plateau had not been reached by the time the experiment was terminated.

The alpha-irradiated $\mathrm{NpO}_{2}$ sample containing $0.5 \mathrm{wt} \% \mathrm{H}_{2} \mathrm{O}$ (equivalent to the limit established for the SRS material) showed a small pressure increase to a steady-state plateau (Fig. 4.14). The gas analysis showed that $\mathrm{H}_{2}$ was produced. A conclusion about the production or depletion of $\mathrm{O}_{2}$ cannot be made for this sample because of excess $\mathrm{O}_{2}$ in the pressure-transducer region. ${ }^{*}$ However, any $\mathrm{O}_{2}$ production should be bounded by the results from the $1 \mathrm{wt} \%$ experiments.

\footnotetext{
*Alpha Np Tube 5 was prepared by opening Alpha Np Tube 1 and adding 0.5 wt $\% \mathrm{H}_{2} \mathrm{O}$. However, the atmosphere in the experimental rig was not purged. Although glove-box air was directly over the $\mathrm{NpO}_{2}$ sample, it is likely that a slug of $\mathrm{O}_{2}$-rich air (from the previous operations on Alpha $\mathrm{Np}$ Tube 1) resided in the transducer region of the experimental rig.
} 


\subsection{OVERVIEW OF RADIOLYTIC MECHANISM}

All of these experiments demonstrate some common trends. First, water radiolysis alone is a rapid process relative to other chemical processes that are occurring simultaneously. Second, when the water content is $\# 1 \%$, the overall pressure in the system generally decreases (or peaks after small pressure increases and then decreases). Third, oxygen is both produced and consumed as a result of radiolytic reactions and, in the long-term, consumption will be the dominant effect. ${ }^{*}$ This consumption is especially evident when oxygen is added during the course of the experiment (see Fig. 4.10). Fourth, limiting pressures (steady-state plateaus) are either reached or approached. Fifth, minor products such as $\mathrm{CO}_{2}$ and $\mathrm{NO}_{x}$ are produced. All of these phenomena are consistent with previously reported fundamental reactions and are discussed separately below.

Water radiolysis was extensively studied more than a half century ago, ${ }^{16,17}$ when it was shown not only that the water is dissociated into primary radical products (ultimately forming $\mathrm{H}_{2}, \mathrm{O}_{2}$ and $\mathrm{H}_{2} \mathrm{O}_{2}$ ), but also that these primary radical products cause back reactions limiting the overall amount of ultimate products. Thus, a steady-state condition is quickly reached in which no further accumulation of ultimate products occurs - one in which the rate of dissociation of water is balanced by its rate of formation. Consequently, extreme gas product pressures from the radiolysis of water are not ordinarily possible.

Accompanying these water radiolysis reactions is another reaction in which the oxygen over solid actinide oxides in such a radiolytically activated system can oxidize the actinide solid (at least partially) to a higher oxidation state. Evidence for this is clearly seen in the oxidation of uranium oxides to higher oxidation states. ${ }^{4,18,19}$ While a direct measurement of the oxidation state of the $\mathrm{NpO}_{2}$ was not made (e.g., via X-ray diffraction), the disappearance of oxygen in the presence of $\mathrm{NpO}_{2}$ is interpreted as being the result of the formation of higher neptunium oxidation states (e.g., $\mathrm{Np}_{2} \mathrm{O}_{5}$ ) - a reaction mechanism analogous to that observed for the uranium oxides. ${ }^{4}$ This reaction largely accounts for the net pressure decrease in the system through the consumption of oxygen.

By using the $\mathrm{NpO}_{2}$ sample from Alpha $\mathrm{Np}$ Tube 1 for the Alpha $\mathrm{Np}$ Tube 5 experiment, the competing reactions of (1) $\mathrm{O}_{2}$ generation and consumption by $\mathrm{H}_{2} \mathrm{O}$ radiolytic chemistry were separated from (2) the $\mathrm{NpO}_{2}$ oxidation reaction. In this case, the $\mathrm{NpO}_{2}$ was "presaturated" with oxygen prior to the addition of water in the Tube 5 test; and when the water was added, only the water radiolysis chemistry was evident (i.e., water radiolysis and back reactions to reach a steady state). The experiment in Tube 5 then showed a gradual rise to a steady-state pressure. Had this $\mathrm{NpO}_{2}$ sample not been presaturated with

\footnotetext{
*Note that both of the alpha-irradiated samples that contained $1 \% \mathrm{H}_{2} \mathrm{O}$ appeared to reach a plateau. However, after withdrawal of a gas sample, the net effect was a pressure decrease. This result indicates that in the long term, a slower-acting mechanism (i.e., one that is slower than the forward-reaction production of $\mathrm{O}_{2}$ ) will result in net $\mathrm{O}_{2}$ consumption.
} 
oxygen, we would predict a profile more like that of Fig. 4.11-one in which after the water radiolysis and back reactions would initially dominate, but then the slower oxygen consumption reaction by the $\mathrm{NpO}_{2}$ would commence and begin to reduce the total pressure of the system.

Additionally, it appears that the radiochemical kinetics of such reactions (radiolysis of water and oxidation of the $\mathrm{NpO}_{2}$ ) may be influenced by the type of radiation. In the case of the highly penetrating gamma radiation, the radiolysis reaction response occurs rapidly, followed by a decrease resulting from the radiolytically influenced oxidation of the $\mathrm{NpO}_{2}$. The overall character of the gamma radiolysis experiments is then one that is dominated by oxidation of $\mathrm{NpO}_{2}$. For the alpha radiolysis experiments, it appears that radiolysis of water dominates for a longer period of time as compared with that observed in the gamma experiments.

Also associated with the above reactions are a number of impurity reactions in which the primary products of water radiolysis combine with the $\mathrm{N}_{2}$ accompanying the $\mathrm{O}_{2}$ in the air atmosphere over the sample or with the carbon that is ubiquitous in many oxide preparations. Thus, trace amounts of $\mathrm{NO}_{x}$ and $\mathrm{CO}_{2}$ are common impurity by-products of such oxide/water radiolysis reactions.

We can therefore explain the overall chemistry taking place during these radiolysis reactions as being a combination of the above phenomena and not just one of these isolated fundamental processes. Initially, a pressure increase often occurs in the encapsulated system, representing both a slight temperature effect and, more importantly, radiolysis of sorbed water to form some hydrogen and oxygen. This water radiolysis would reach a steady-state pressure were it not for the reaction of oxygen with the actinide oxide to form a higher oxidation state of the actinide and thus decrease the oxygen content of the atmosphere over the system. Evidence for this is seen in the "dry" oxide radiolysis experiments, in which there is no pressure increase (because there is no water to be radiolyzed) — only oxygen consumption. When there is an excessive amount of moisture (e.g., $8 \%$, a case in which water would have to actually condense and puddle on the oxide), the water radiolysis reaction is dominant. Nevertheless, even here, all of the water on the sample is not radiolyzed, because of the accompanying back reactions of the primary water radiolytic products (i.e., the radicals) with the water products $\left(\mathrm{H}_{2}, \mathrm{O}_{2}\right.$, etc.). 


\section{CONCLUSIONS}

Two key results were demonstrated in these experiments. First, the water uptake experiments clearly indicated that the $0.5 \mathrm{wt} \%$ moisture limit that has been typically established for similar materials (e.g., uranium and plutonium oxides) $)^{9,10}$ cannot be obtained in a practical environment. In fact, the uptake in a typical environment can be expected to be at least an order of magnitude less than this limit.

The second key result is the establishment of steady-state plateaus. These plateaus illustrate the presence of back reactions that limit the overall pressure increase and $\mathrm{H}_{2}$ production. For example, in the case of the $\mathrm{NpO}_{2}$ alpha radiolysis experiments containing $1 \mathrm{wt} \% \mathrm{H}_{2} \mathrm{O}$, total decomposition of all the $\mathrm{H}_{2} \mathrm{O}$ into $\mathrm{H}_{2}$ and $\mathrm{O}_{2}$ would result in a pressure increase of about 3450 torr. However, for these experiments, the actual pressure increase was only 140-250 torr. Similarly, for the alpha-irradiated $0.5 \mathrm{wt} \% \mathrm{H}_{2} \mathrm{O}$ sample, total decomposition would result in a pressure increase of about 1750 torr, while a rise of only 50 torr was observed. These results clearly demonstrate that $0.5 \mathrm{wt} \% \mathrm{H}_{2} \mathrm{O}$ on $\mathrm{NpO}_{2}$ is safe for long-term storage — if such a moisture content could ever be practically reached. Additionally, there is evidence that another mechanism plays a role in $\mathrm{O}_{2}$ consumption; namely, radiolytically-influenced oxidation of the $\mathrm{NpO}_{2}$. This mechanism further limits pressurization in the long term.

In setting the storage standards for the actinide oxides, it has customarily been assumed ${ }^{9,10}$ that radiolysis of sorbed moisture would produce stoichiometric amounts of $\mathrm{H}_{2}$ and $\mathrm{O}_{2}$ and would continue until all of the water had been radiolyzed to these products. However, these results support the observations of other laboratories that many other radiolytic reactions are concurrently active in such radiolytic processes and thus limit the overall accumulation of these products. 


\section{REFERENCES}

1. A. S. Icenhour, L. M. Toth, G. D. Del Cul, and L. F. Miller, "Gamma Radiolysis Studies of Uranyl Fluoride," Radiochim. Acta 90, 109-122 (2002).

2. A. S. Icenhour and L. M. Toth, Gamma Radiolysis Study of $\mathrm{UO}_{2} \mathrm{~F}_{2} \cdot 0.4 \mathrm{H}_{2} \mathrm{O}$ Using Spent Nuclear Fuel Elements from the High Flux Isotope Reactor, ORNL/TM-2001/138, UT-Battelle, LLC, Oak Ridge National Laboratory, Oak Ridge, Tennessee, January 2002.

3. A. S. Icenhour, L. M. Toth, and H. Luo, Water Sorption and Gamma Radiolysis Studies for Uranium Oxides, ORNL/TM-2001/59, UT-Battelle, LLC, Oak Ridge National Laboratory, Oak Ridge, Tennessee, February 2002.

4. A. S. Icenhour and L. M. Toth, Alpha Radiolysis of Sorbed Water on Uranium Oxides and Uranium Oxyfluorides, ORNL/TM-2003/172, UT-Battelle, LLC, Oak Ridge National Laboratory, Oak Ridge, Tennessee, September 2003.

5. "Np Oxide Material Specification Agreement between the Savannah River Site and the Oak Ridge National Laboratory for the transfer of Neptunium Oxide," NMM-PRG-2002-011.7, Rev. 0, December 2002.

6. "Np Oxide Packaging Agreement between the Savannah River Site and the Oak Ridge National Laboratory for the Transfer of Neptunium Oxide," CBU-HCP-2003-00033, Rev. 0, March 2003.

7. J. A. Porter, "Production Technology of Neptunium-237 and Plutonium-238," pp. 289-293 in Proceedings of the Symposium on Production Technology of Neptunium-237 and Plutonium-238, $146^{\text {th }}$ Meeting of the American Chemical Society, January 1964, Vol. 3, Issue 4, American Chemical Society, Washington, D.C., 1964.

8. A. S. Icenhour, Radiolytic Effects on Fluoride Impurities in a $U_{3} O_{8}$ Matrix, ORNL/TM-2000/157, UTBattelle, LLC, Oak Ridge National Laboratory, Oak Ridge, Tennessee, May 2000.

9. Criteria for Packaging and Storing Uranium-233-Bearing Materials, DOE-STD-3028-2000, U.S. Department of Energy, Washington, D.C.

10. Criteria for Preparing and Packaging Plutonium Metals and Oxides for Long-term Storage, DOESTD-3013, U.S. Department of Energy, Washington, D.C.

11. J. M. Duffey and R. R. Livingston, Characterization of Neptunium Oxide Generated Using the HBLine Phase II Flowsheet, WSRC-TR-2003-00388, Rev. 0, Westinghouse Savannah River Company, Savannah River Site, Aiken, S.C., August 2003.

12. CRC Handbook of Chemistry and Physics, $73^{\text {rd }}$ ed., D. R. Lide, ed., CRC Press, Boca Raton, Florida, 1992.

13. W. Primak and L. H. Fuchs, "Nitrogen Fixation in a Nuclear Reactor," Nucleonics 13(2), 38-41 (1955).

14. P. Harteck and S. Dondes, "Producing Chemicals with Reactor Radiations," Nucleonics 14(7), 22-25 (1956). 
15. A. R. Jones, "Radiation-Induced Reactions in the $\mathrm{N}_{2}-\mathrm{O}_{2}-\mathrm{H}_{2} \mathrm{O}$ System," Radiat. Res. 10, 655-663 (1959).

16. C. J. Hochanadel, "Effects of Cobalt Gamma-Radiation on Water and Aqueous Solutions," J. Phys. Chem. 56(5), 587-94 (1952).

17. A. O. Allen, C. J. Hochanadel, J. A. Ghormley, and T. W. Davis, "Decomposition of Water and Aqueous Solutions Under Mixed Fast Neutron and Gamma Radiation," J. Phys. Chem. 56(5), 575-86 (1952).

18. G. Sattonnay et al., "Alpha-Radiolysis Effects on $\mathrm{UO}_{2}$ Alteration in Water," J. Nucl. Mater. 288, 11-19 (2001).

19. P. C. Burns and K. Hughes, "Studtite $\left[\left(\mathrm{UO}_{2}\right)\left(\mathrm{O}_{2}\right)\left(\mathrm{H}_{2} \mathrm{O}\right)_{2}\right]\left(\mathrm{H}_{2} \mathrm{O}\right)_{2}$ : The First Structure of a Peroxide Mineral," Am. Mineral., 88, 1165-68 (2003). 
ORNL/TM-2003/194

\section{INTERNAL DISTRIBUTION}

1. C. W. Alexander

2. J. M. Begovich

3. W. D. Bond

4-5. R. R. Brunson

6. R. M. Canon

7. T. B. Conley

8. G. D. Del Cul

9. R. H. Elwood, Jr.

10. L. K. Felker

11. L. L. Gilpin

12. S. Goluoglu

13. M. A. Green

14. J. N. Herndon

15. D. J. Hill

16. C. M. Hopper

17-21. A. S. Icenhour

22. A. M. Krichinsky
23. B. E. Lewis

24. S. C. Marschman

25. D. E. Mueller

26. P. E. Osborne

27. C. V. Parks

28. D. A. Reed

29. J. E. Rushton

30. C. M. Simmons

31. D. W. Simmons

32. R. G. Taylor

33-34. L. M. Toth

35. L. D. Trowbridge

36. R. M. Westfall

37-41. R. M. Wham

42. D. F. Williams

43. NSTD DMC

44. OTIC-RC, OSTI, CRL

\section{EXTERNAL DISTRIBUTION}

45. N. M. Askew, U.S. Department of Energy, Savannah River Site Operations Office, WSRC, Bldg. 773-A, Road 1A, Aiken, SC 29801

46. L. W. Boyd, DOE-ORO, U.S. Department of Energy, P.O. Box 2008 MS-6269, Oak Ridge, TN 37831

47. W. R. Brock, BWXT-Y-12, LLC, P.O. Box 2009, Oak Ridge, TN 37831

48. W. P. Carroll, DOE-HQ, NE-40/Germantown Building, U.S. Department of Energy, 1000 Independence Ave. S.W., Washington, DC 20585-1290

49. S. O. Cox, BWXT-Y-12, LLC, P.O. Box 2009, Oak Ridge, TN 37831

50. C. H. Delegard, Pacific Northwest National Laboratory, 902 Battelle Blvd., P.O. Box 999, Richland, WA 99352

51. J. M. Duffey, U.S. Department of Energy, Savannah River Site Operations Office, WSRC, Bldg. 773-A, Road 1A, Aiken, SC 29801

52. P. G. Eller, U.S. Department of Energy, Los Alamos National Laboratory, P.O. Box 1663, Los Alamos, NM 87545

53. H. C. Johnson, U.S. Department of Energy, Headquarters, EM-21, Forrestal Bldg., 1000 Independence Ave. S.W., Washington, D.C. 20585

54. R. A. Just, BWXT-Y-12, LLC, P.O. Box 2009, Oak Ridge, TN 37831

55. H. J. Keener, BWXT-Y-12, LLC, P.O. Box 2009, Oak Ridge, TN 37831

56. E. Kendall, NNSA, U.S. Department of Energy, P.O. Box 2001 MS-8193, Oak Ridge, TN 37831

57. R. R. Livingston, U.S. Department of Energy, Savannah River Site Operations Office, WSRC, Bldg. 773-A, Road 1A, Aiken, SC 29801

58. R. E. Mason, U.S. Department of Energy, Los Alamos National Laboratory, P.O. Box 1663, Los Alamos, NM, 87545 
59. R. C. McBroom, DOE-ORO, U.S. Department of Energy, P.O. Box 2008 MS-6269, Oak Ridge, TN 37831

60. S. R. Martin, Jr., DOE-ORO, U.S. Department of Energy, P.O. Box 2008 MS-6269, Oak Ridge, TN 37831

61. T. R. Miller, BWXT-Y-12, LLC, P.O. Box 2009, Oak Ridge, TN 37831

62. L. Morales, U.S. Department of Energy, Los Alamos National Laboratory, P.O. Box 1663, Los Alamos, NM, 87545

63. M. T. Paffett, U.S. Department of Energy, Los Alamos National Laboratory, P.O. Box 1663, Los Alamos, NM, 87545

64. M. J. Plaster, BWXT-Y-12, LLC, P.O. Box 2009, Oak Ridge, TN 37831

65. K. H. Reynolds, DOE-ORO, U.S. Department of Energy, P.O. Box 2008 MS-6269, Oak Ridge, TN 37831

66. G. D. Roberson, U.S. Department of Energy, Albuquerque Operations Office, Bldg. 382-2, AL, Pennsylvania and H Street, Kirkland Air Force Base, Albuquerque, NM 87116

67. L. A. Worl, U.S. Department of Energy, Los Alamos National Laboratory, P.O. Box 1663, Los Alamos, NM 87545 